\title{
Alkali Metal-Cationized Serine Clusters Studied by Sonic Spray Ionization Tandem Mass Spectrometry
}

\author{
Sergio C. Nanita, ${ }^{*}$ Ewa Sokol, and R. Graham Cooks \\ Department of Chemistry, Purdue University, West Lafayette, Indiana, USA
}

\begin{abstract}
Serine solutions containing salts of alkali metals yield magic number clusters of the type $\left(\mathrm{Ser}_{4}+\mathrm{C}\right)^{+},\left(\mathrm{Ser}_{8}+\mathrm{C}\right)^{+},\left(\mathrm{Ser}_{12}+\mathrm{C}\right)^{+}$, and $\left(\mathrm{Ser}_{17}+2 \mathrm{C}\right)^{+2}\left(\right.$ where $\mathrm{C}=\mathrm{Li}^{+}, \mathrm{Na}^{+}, \mathrm{K}^{+}, \mathrm{Rb}^{+}$, or Cs $\left.^{+}\right)$, in relative abundances which are strongly dependent on the cation size. Strong selectivity for homochirality is involved in the formation of serine tetramers cationized by $\mathrm{K}^{+}, \mathrm{Rb}^{+}$, and $\mathrm{Cs}^{+}$. This is also the case for the octamers cationized by the smaller alkalis but there is a strong preference for heterochirality in the octamers cationized by the larger alkali cations. Tandem mass spectrometry shows that the octamers and dodecamers cationized by $\mathrm{K}^{+}, \mathrm{Rb}^{+}$, and $\mathrm{Cs}^{+}$ dissociate mainly by the loss of $\mathrm{Ser}_{4}$ units, suggesting that the neutral tetramers are the stable building blocks of the observed larger aggregates, $\left(\mathrm{Ser}_{8}+\mathrm{C}\right)^{+}$and $\left(\mathrm{Ser}_{12}+\mathrm{C}\right)^{+}$. Remarkably, although the $\mathrm{Ser}_{4}$ units are formed with a strong preference for homochirality, they aggregate further regardless of their handedness and, therefore, with a preference for the nominally racemic 4D:4L structure and an overall strong heterochiral preference. The octamers cationized by $\mathrm{K}^{+}, \mathrm{Rb}^{+}$, or $\mathrm{Cs}^{+}$therefore represent a new type of cluster ion that is homochiral in its internal subunits, which then assemble in a random fashion to form octamers. We tentatively interpret the homochirality of these tetramers as a consequence of assembly of the serine molecules around a central metal ion. The data provide additional evidence that the neutral serine octamer is homochiral and is readily cationized by smaller ions. (J Am Soc Mass Spectrom 2007, 18, 856-868) @ 2007 American Society for Mass Spectrometry
\end{abstract}

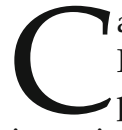
ations of the alkali metals, especially $\mathrm{Na}^{+}$and $\mathrm{K}^{+}$, are involved in a wide variety of biological ipate in the stabilization of noncovalently bound complexes of biological macromolecules in living organisms. In particular, telomeric DNA found at the ends of chromosomes is stabilized by forming multistrand complexes, known as G-quadruplexes, which are held together by hydrogen bonds and further stabilized by the incorporation of alkali metal cations into cavities in their structures [1-3]. Mass spectrometry [1], nuclear magnetic resonance, X-ray crystallography and other spectroscopic techniques have shown that small biomolecules can also form relatively stable clusters with alkali metal cations. Examples include nucleobases [4-6] and nucleosides (as well as their derivatives) [7-9], and amino acids [10, 11]. A particular feature of alkali metal adducts of small molecular clusters is that they often have a net positive charge and can be characterized by mass spectrometry, a technology that has proven to be key in many studies of clusters [11-19].

Published online March 7, 2007

Address reprint requests to Dr. R. G. Cooks, Department of Chemistry, Purdue University, 560 Oval Dr., West Lafayette, IN 47907, USA. E-mail: cooks@purdue.edu

* Current address: DuPont Crop Protection, Stine-Haskell Research Center, 1090 Elkton Rd, S315/1220, Newark, DE 19711, USA.
Electrospray ionization (ESI) [20, 21] is a versatile ionization technique, which allows biological macromolecules, fragile noncovalently bound complexes [2226], and other fragile nonvolatile species to be easily transferred from solution into the gas-phase, where mass spectral data can be obtained on the resulting ions. Although the possibility exists of conformational rearrangement $[27,28]$ and other structural changes during the ESI process, there is overwhelming evidence that electrospray ionization is successful in the characterization of solution-phase species via a study of the corresponding gas-phase ions [24, 26]. Spray ionization methods derived from the original ESI method include sonic spray ionization (SSI) [29, 30] and cold spray ionization (CSI) [31, 32]. Recently, electrosonic spray ionization (ESSI) [33, 34], a combination of ESI and SSI, was introduced. This particular spray ionization method is very gentle, yet readily yields fully desolvated ions [33, 34]. The variant methods SSI, CSI, and ESSI are all believed to provide gentler ionization than normal electrospray, allowing labile species that exist in solution to survive the ionization process as well as being applicable to nonvolatile analytes.

The droplet evaporation process in the gentle variant methods on ESI can lead to even more aggregation than occurs in ESI itself. This tendency has been found to be critical in the study of biological systems, where the 
mildness of SSI, CSI, and ESSI has already been successfully employed in the study of fragile noncovalently bound complexes [32-36], in some cases yielding better signal-to-noise ratios than those obtained with ESI [32, 33, 35]. The clustering behavior retained when using these methods is also particularly useful for fundamental studies of cluster ions.

Clusters of the amino acid serine, especially the magic number octamer, represent a subject of some interest within the larger topic of supramolecular clusters [37-42]. Various research groups have studied clusters of this amino acid using both ESI and SSI mass spectrometry [35-63], motivated by earlier studies which showed that the formation of protonated serine octamers occurs with a remarkably strong preference for homochirality [37-41]. The chemistry of the ionized serine octamer in the presence of compounds of biochemical significance, such as other coding amino acids, sugars, phosphoric acid, and transition-metal cations, has also been investigated [44, 46, 63]. Briefly, these studies show that serine octamers undergo chiroselective substitution reactions in which serine molecules in the homochiral octamer are replaced by other amino acids or sugars, resulting in mixed serine/amino acid and serine/saccharide noncovalently-bound clusters. These reactions favor the enantiomers present in living systems, which supports the idea that homochiral serine octamers might have been involved in prebiotic mechanisms that led to the accumulation and transmission of homochirality [44, 46, 63].

Tandem mass spectrometry $[38,41,56]$, ion mobility cross section measurements [36, 40, 41], theoretical calculations [38-41, 45], and hydrogen/deuterium exchange reactions [47-49,57-61] have all been used to gain information about the structure(s) of serine clusters. These studies have demonstrated that there are two structural types of protonated serine octamers and that at least one is composed of zwitterionic monomers.

The interactions between amino acids and alkali metal cations were studied previously by electrospray ionization mass spectrometry [10]. In the case of serine, only the protonated [35-59] and halide adducts [62] of serine clusters were characterized to any degree. This paper discusses the clustering of serine in the presence of alkali metal ions and reports that alkali-metalcationized serine clusters $\left(\mathrm{Ser}_{4}+\mathrm{C}\right)^{+},\left(\mathrm{Ser}_{8}+\mathrm{C}\right)^{+}$, $\left(\operatorname{Ser}_{12}+\mathrm{C}\right)^{+}$, and $\left(\operatorname{Ser}_{17}+2 \mathrm{C}\right)^{+2}($ where $\mathrm{C}=$ alkali metal cation) are detected as magic number (particularly stable) clusters and that their abundances relative to each other are strongly dependent on the cation size. Tandem mass spectrometry is used to reveal that the $\left(\mathrm{Ser}_{12}+\mathrm{C}\right)^{+}$adducts are derivatives of smaller alkalimetal-cationized serine clusters (i.e., octamers and tetramers). The chiral selectivity involved in the formation of alkali-metal-cationized serine clusters is studied by analyzing mixtures of D-serine and deuterated L-serine and a remarkable preference for homochirality is observed in the formation of serine tetramers with the cations $\mathrm{K}^{+}, \mathrm{Rb}^{+}$, and $\mathrm{Cs}^{+}$, but not with $\mathrm{Li}^{+}$or $\mathrm{Na}^{+}$. The opposite tendency is observed in the formation of serine octamers. In the presence of $\mathrm{Li}^{+}$and $\mathrm{Na}^{+}$, homochiral serine octamers are favored but this is not the case for the clusters cationized by $\mathrm{K}^{+}, \mathrm{Rb}^{+}$, or $\mathrm{Cs}^{+}$.

\section{Experimental}

A Thermo Finnigan LCQ quadrupole ion trap mass spectrometer (San Jose, CA) equipped with a homebuilt sonic spray ionization source [35] was used to record mass spectra. For experiments that required higher sensitivity (i.e., breakdown plots showing spectra as a function of collision energy and isotopic labeling studies) a Thermo Electron Corporation LTQ (San Jose, CA) linear ion trap mass spectrometer was used. Detailed information about the home-built SSI source is available elsewhere [35]. The $^{\circ}$ amino $^{\circ}$ acid $^{\circ}$ serine $^{\circ}$ was obtained from Sigma Co. (St. Louis, MO). Isotopically labeled serine $\left(2,3,3-\mathrm{d}_{3}\right.$-L-serine, nominal isotopic purity, 98\%) was purchased from Cambridge Isotope Laboratories, Inc. (Andover, MA). Methanol was obtained from Mallinckrodt (Paris, KY) and used to prepare the spray solvent mixture $(50 \% \mathrm{vol} / \mathrm{vol}$ in water). The alkali metal salts $\mathrm{LiCl}, \mathrm{RbCl}$, and $\mathrm{CsCl}$ were purchased from Aldrich (Milwaukee, WI), while $\mathrm{NaCl}$ and $\mathrm{KCl}$ were purchased from Mallinckrodt (Paris, KY) and used without further purification. Acetic acid and hydrochloric acid solutions were used as sources of protons and both gave similar results. All mass spectra were recorded under identical analytical conditions. Parameters included: serine concentration $5.0 \mathrm{mM}$, alkali-metal salt concentration $0.25 \mathrm{mM}$, sample solution flow rate $5 \mu \mathrm{L} / \mathrm{min}$, sheath gas pressure $120 \mathrm{psi}$, heated capillary temperature $100{ }^{\circ} \mathrm{C}$, LCQ heated capillary voltage $7 \mathrm{~V}$, and tube lens off set $50 \mathrm{~V}$, LTQ heated capillary voltage $10 \mathrm{~V}$ and tube lens voltage $70 \mathrm{~V}$. Tandem mass spectra (product ion spectra) were recorded by isolating the parent ion(s) of interest using a notched waveform of full width 20 to 60 mass/charge units. Note that a larger than usual isolation window was used in isotopic labeling experiments to isolate entirely the desired isotopic distribution of serine clusters. Dissociation of the selected precursor ions was subsequently achieved through collisional activation with helium buffer gas. The collision energy was optimized for each experiment and is expressed in terms of the manufacturer's nominal relative collision energy (\%), where the range from 0 to $100 \%$ corresponds to a resonance excitation AC signal of 0 to $2.5 \mathrm{~V}$ (zero-topeak) at the secular frequency of the ion of interest. The charge states of the cluster ions were determined by mass/charge ratio measurements and in some cases confirmed by cation labeling (recording spectra from samples containing a mixture of $\mathrm{Rb}^{+}$and $\mathrm{Cs}^{+}$). Tandem mass spectrometry was also employed to verify the charge states of the cluster ions. 


\section{Results and Discussion}

\section{Serine/Alkali Metal Mixtures}

Samples containing serine and an alkali metal salt were analyzed by sonic spray ionization mass spectrometry. The corresponding protonated species were studied for comparison. Alkali-metal-cationized serine clusters are readily $^{\circ}$ formed $^{\circ}$ and $^{\circ}$ Figure $^{\circ} 1^{\circ}$ displays ${ }^{\circ}$ representative sonic spray mass spectra, where clusters of the type $\left(\operatorname{Ser}_{4}+\mathrm{C}\right)^{+},\left(\operatorname{Ser}_{8}+\mathrm{C}\right)^{+},\left(\operatorname{Ser}_{12}+\mathrm{C}\right)^{+}$, and $\left(\operatorname{Ser}_{17}+2 \mathrm{C}\right)^{+2}$, where $\mathrm{C}=$ proton or alkali cation, appear to be particularly stable (for particular cations). Relative abundances of cluster ions vary strongly as a function of cation size. For example, the relative abundances of serine octamers decrease as the cation size increases. The opposite occurs for $\left(\operatorname{Ser}_{12}+\mathrm{C}\right)^{+}$and $\left(\operatorname{Ser}_{17}+2 \mathrm{C}\right)^{+2}$ while $\left(\mathrm{Ser}_{4}+\mathrm{C}\right)^{+}$shows a maximum at intermediate cation sizes.

A convenient way to compare relative abundances of serine clusters formed in the presence of alkali metal ions $^{\circ}$ is $^{\circ}$ as $^{\circ}$ the ${ }^{\circ}$ magic $^{\circ}$ number ${ }^{\circ}$ factor ${ }^{\circ}[64] .{ }^{\circ}$ This $^{\circ}$ scaling factor represents the relative intensity of a cluster of interest compared with its neighbors. A magic number is a cluster size that is relatively stable compared with its neighboring sizes. The following equation gives a quantitative measure of just how "magic" a given cluster ${ }^{\circ}$ is $^{\circ}[64]$ :

$$
\text { Magic number factor }=\frac{I_{n}^{2}}{I_{n-1} \times I_{n+1}}
$$

where $n$ is the cluster size and $I$ is the signal intensity of the corresponding cluster ion. Note that a magic number factor $>1$ implies that the particular cluster ion is favored over its neighbors, while a cluster of size $n$ with magic number factor $<1$ is less stable.

Experiments were performed to quantify, using eq 1, the magic number character of the cluster ions $\left(\operatorname{Ser}_{4}+\mathrm{C}\right)^{+},\left(\operatorname{Ser}_{8}+\mathrm{C}\right)^{+},\left(\operatorname{Ser}_{12}+\mathrm{C}\right)^{+}$, and $\left(\operatorname{Ser}_{17}+2 \mathrm{C}\right)^{+2}$, as a function of cation size and the resulting data are shown ${ }^{\circ}{ }^{\circ}{ }^{\circ}$ igure $^{\circ} 2 .^{\circ}{ }^{A} n^{\circ}$ intriguing ${ }^{\circ}$ feature ${ }^{\circ}$ of ${ }^{\circ}$ Figure $^{\circ} 2^{\circ}$ is the magnitude of the magic number factors of the clusters. Four serine clusters have remarkably large magic number factors, under optimized conditions: 72, 747, 22, and 142 for $\left(\operatorname{Ser}_{4}+\mathrm{K}\right)^{+},\left(\operatorname{Ser}_{8}+\mathrm{H}\right)^{+},\left(\mathrm{Ser}_{12}+\mathrm{Cs}\right)^{+}$, and $\left(\mathrm{Ser}_{17}+2 \mathrm{Cs}\right)^{+2}$, respectively. Serine forms particularly stable tetramers with potassium, rubidium, and cesium. The large magic number factor obtained for $\left(\mathrm{Ser}_{4}+\mathrm{K}\right)^{+}{ }^{\circ}\left(\text { see }^{\circ} \text { Figure }^{\circ} 2 \mathrm{a}\right)^{\circ}{ }^{\circ}$ appears ${ }^{\circ}$ to $^{\circ}$ indicate ${ }^{\circ} \mathrm{a}^{\circ}$ change in the tetramer structure between $\mathrm{Na}^{+}$and $\mathrm{K}^{+}$. For this reason, these two systems were carefully characterized using isotopic labeling as will be discussed in the next section.

Turning to the serine octamers, stability as measured by the magic number factor is seen to decrease with cation size, the protonated species being the most favorable of all the cationic forms studied. This (very indirect) evidence points towards the possible existence of highly stable neutral octamers of serine as previously hypothesized ${ }^{\circ}[62],{ }^{\circ}$ and $^{\circ}$ as $^{\circ}$ demonstrated $^{\circ}$ by $^{\circ}$ ionizing neutral ${ }^{\circ}$ serine ${ }^{\circ}$ octamers $^{\circ}[54] .^{\circ}$ On $^{\circ}$ the ${ }^{\circ}$ other ${ }^{\circ}$ hand, ${ }^{\circ}$ and ${ }^{\circ}$ as seen $^{\circ}$ in $^{\circ}$ Figure $^{\circ} 2 \mathrm{c}^{\circ}$ and $^{\circ} \mathrm{d}^{\circ}$, the $^{\circ}$ larger ${ }^{\circ}$ aggregates, $\left(\operatorname{Ser}_{12}+\mathrm{C}\right)^{+}$and $\left(\operatorname{Ser}_{17}+2 \mathrm{C}\right)^{+2}$, are preferentially formed in the presence of $\mathrm{Rb}^{+}$and $\mathrm{Cs}^{+}$. Note that the 17-mers appear as both singly-charged and doubly-charged ions.

The effect of the heated capillary temperature on cluster formation was also investigated. This parameter was varied to evaluate its effect on the magic number factor ${ }^{\circ}$ of $^{\circ}$ the $^{\circ}$ cluster $^{\circ}$ ions. $^{\circ}$ The $^{\circ}$ results $^{\circ}\left(\text { Figure }^{\circ} 2\right)^{\circ}$ show that the magic number character of $\left(\mathrm{Ser}_{4}+\mathrm{C}\right)^{+}$, $\left(\operatorname{Ser}_{8}+\mathrm{C}\right)^{+},\left(\operatorname{Ser}_{12}+\mathrm{C}\right)^{+}$, and $\left(\operatorname{Ser}_{17}+2 \mathrm{C}\right)^{+2}$ follows the same general trend with respect to the cation size at different capillary temperatures. However, the magic number factor of a cluster ion can be enhanced by adjusting the temperature, causing the less stable neighbor clusters to dissociate preferentially. For example, the magic number value of $\left(\operatorname{Ser}_{17}+2 \mathrm{Cs}\right)^{+2}$ increases from 56 to 142 when the heated capillary temperature is raised from 85 to $130{ }^{\circ} \mathrm{C}$. At even higher temperature, the scaled intensity typically drops due to extensive dissociation of all the clusters. This can clearly be seen in ${ }^{\circ}$ Figure $^{\circ} 2^{\circ}$ for $^{\circ}$ tetramers, ${ }^{\circ}$ octamers, ${ }^{\circ}$ dodecamers, ${ }^{\circ}$ and heptadecamers.

\section{Serine Tetramers}

Chiral effects. The chiral preferences associated with formation of the smallest magic number aggregates, $\left(\mathrm{Ser}_{4}+\mathrm{C}\right)^{+}$, were characterized by isotope labeling. Isotopically labeled serine $\left(2,3,3-\mathrm{d}_{3}-\mathrm{L}\right.$-serine $)$ was used to prepare $10 \mathrm{mM}$ solutions of racemic serine $(5 \mathrm{mM}$

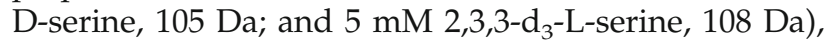
which also contained a salt of the alkali metal cation of interest. Sonic spray mass spectra of these samples were recorded and used to study the chiral preferences occurring in the formation of serine tetramers cationized by alkali metals. The resulting data for $\mathrm{Na}^{+}$and $\mathrm{K}^{+}$ cationized ${ }^{\circ}$ tetramers $^{\circ}$ are $^{\circ}$ shown $^{\circ}$ in ${ }^{\circ}$ Figure $^{\circ} 3$.

The ${ }^{\circ}$ data ${ }^{\circ}$ obtained ${ }^{\circ}$ for $^{\circ}$ sodiated $^{\circ}$ tetramers $^{\circ}$ (Figure $\left.3 a\right)$ show an approximately statistical distribution of the five isomeric clusters: 4D:0L $(m / z 443), 3 D: 1 L(m / z 446)$, 2D:2L ( $m / z 449), 1 \mathrm{D}: 3 \mathrm{~L}(\mathrm{~m} / \mathrm{z} 452)$, and 0D:4L $(\mathrm{m} / \mathrm{z} 455)$. This implies that the $\left(\mathrm{Ser}_{4}+\mathrm{Na}\right)^{+}$ions are formed without regard to the chirality of serine, although there is a slightly enhanced preference for the heterochiral form, shown by the enhanced magnitude of the 2D:2L ion. By contrast, the spectrum recorded for the solution containing potassium revealed that the homochiral $\left(\mathrm{Ser}_{4}+\mathrm{K}\right)^{+}$clusters are greatly enhanced in abundance (see ${ }^{\circ}$ Figure $^{\circ} 3 \mathrm{~b},{ }^{\circ}$ which $^{\circ}$ shows ${ }^{\circ}$ that ${ }^{\circ}$ the ${ }^{\circ} 4 \mathrm{D}: 0 \mathrm{~L}^{\circ}$ and $^{\circ} 0 \mathrm{D}: 4 \mathrm{~L}$ forms have the greatest abundance; it also shows a contribution from a minor heterochiral form indicated by the enhanced abundance of the 2D:2L relative to the 3D:1L and 1D:3L forms). This dramatic change in chiral preference of the tetramers on changing the cation from sodium to potassium strongly suggests a change in 


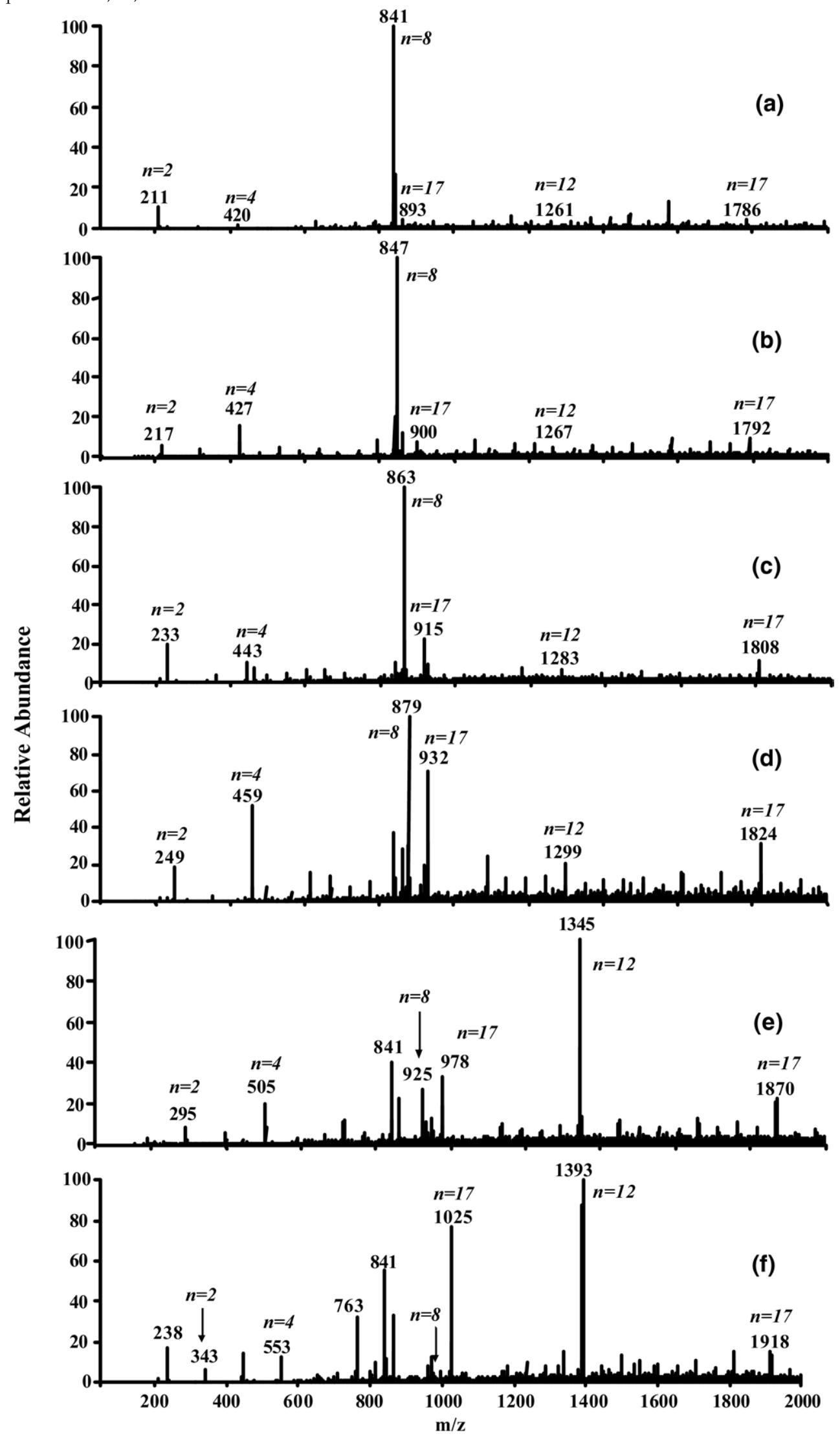

Figure 1. Sonic spray ionization (SSI) mass spectra of solutions containing L-serine and (a) acetic acid (HAc), (b) $\mathrm{LiCl},(\mathbf{c}) \mathrm{NaCl}$, (d) $\mathrm{KCl}$, (e) $\mathrm{RbCl}$, and (f) $\mathrm{CsCl}$. The six spectra were recorded under identical conditions. Note that in particular spectra the clusters $\left(\operatorname{Ser}_{4}+\mathrm{C}\right)^{+},\left(\mathrm{Ser}_{8}+\mathrm{C}\right)^{+},\left(\mathrm{Ser}_{17}+2 \mathrm{C}\right)^{+2}$, $\left(\operatorname{Ser}_{12}+\mathrm{C}\right)^{+}$, and $\left(\operatorname{Ser}_{17}+\mathrm{C}\right)^{+}$appear as magic number clusters. Note also that serine 17-mers are abundant as both singly- and doubly-charged ions, particularly when cationized by the larger metals. 
(a)

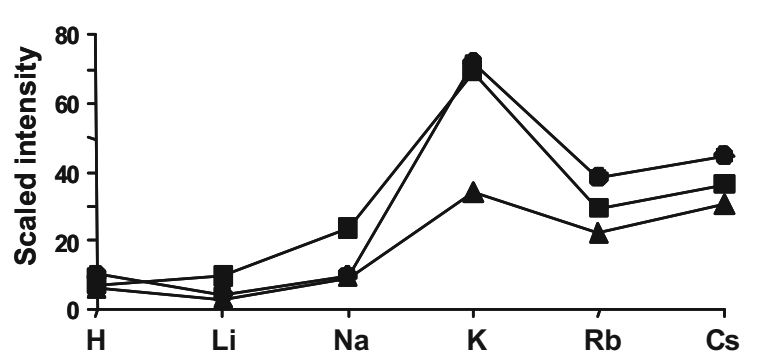

(c)

4-mer

12-mer

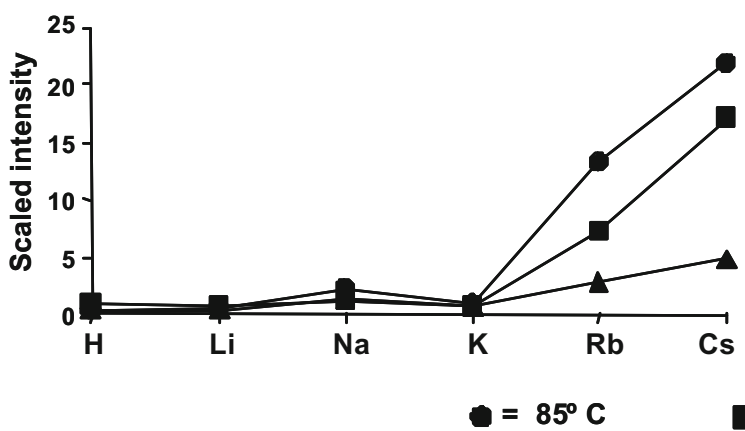

(b)

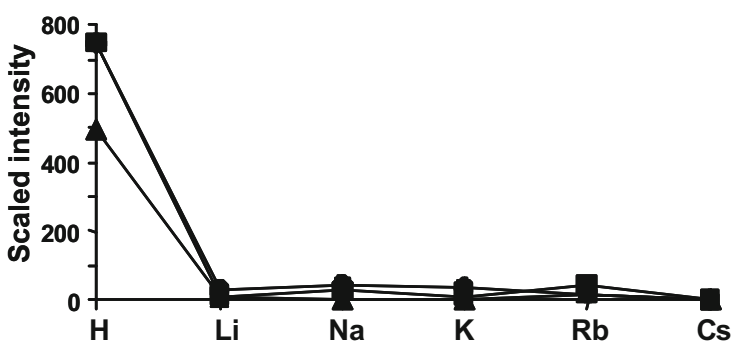

(d)

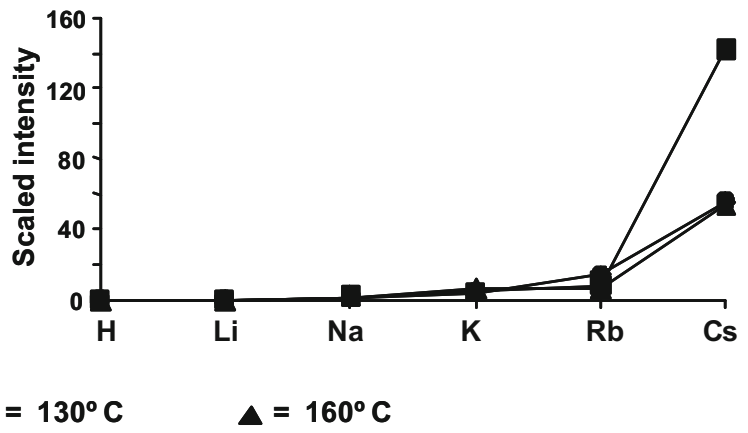

Figure 2. Scaled intensity showing serine cluster magic number character (calculated from eq 1) plotted as a function of cation size for various heated capillary temperatures. The data correspond to $(\mathbf{a})\left(\mathrm{Ser}_{4}+\mathrm{C}\right)^{+},(\mathbf{b})\left(\operatorname{Ser}_{8}+\mathrm{C}\right)^{+}$, (c) $\left(\operatorname{Ser}_{12}+\mathrm{C}\right)^{+}$, and $(\mathbf{d})\left(\operatorname{Ser}_{17}+2 \mathrm{C}\right)^{+2}$; where $\mathrm{C}=\mathrm{H}, \mathrm{Li}, \mathrm{Na}, \mathrm{K}, \mathrm{Rb}$, or Cs.

structure of the corresponding tetramers. As a secondary feature, the data also suggest that two forms of at least the potassiated cluster are likely involved.

To allow comparison with other clusters and to provide a quantitative basis for assigning homo- or heterochiral preferences, the relative abundances of the various homochiral and heterochiral serine aggregates within a particular cluster type (e.g., the sodiated serine tetramer) were normalized. The isotopic distributions of the cationized serine tetramers, octamers, 12-mers and 17-mers were expressed as the probabilities:

$$
P_{i}=\frac{I_{i}}{\sum_{i=1}^{n} I_{i}}
$$

where $P_{i}$ is a normalized intensity of the $i$ th ion within the cluster population of all clusters containing $n$
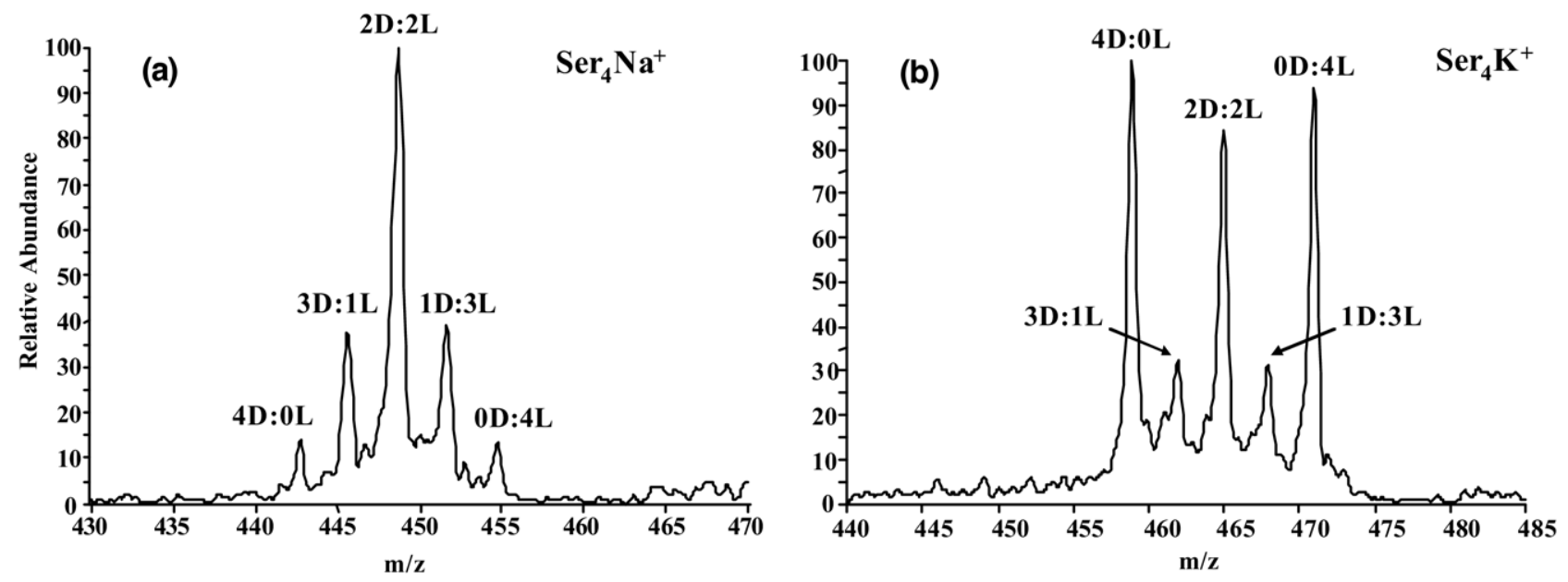

Figure 3. Chiral effects associated with the formation of serine tetramers identified by isotopically labeling one enantiomer $\left(2,3,3-\mathrm{d}_{3}\right.$-L-serine, $\left.108 \mathrm{Da}\right)$. SSI-MS of solutions containing 2,3,3- $\mathrm{d}_{3}$-L-serine $(5 \mathrm{mM})$, D-serine $(5 \mathrm{mM})$ and (a) $0.25 \mathrm{mM} \mathrm{NaCl}$ or (b) $0.25 \mathrm{mM} \mathrm{KCl}$. Chiral effects are small in the formation of $\left(\mathrm{Ser}_{4}+\mathrm{Na}\right)^{+}$clusters, while a strong preference for homochirality is observed in $\left(\mathrm{Ser}_{4}+\mathrm{K}\right)^{+}$. 
serines and a particular cation and $I_{i}$ is the signal intensity for this particular cluster ion.

A numerical chiral preference was obtained by comparing the normalized intensity to the statistical distribution of the cluster population as calculated from the binomial distribution. The variance between the statistical distribution and the experimental data was taken to represent the square of the chiral preference $(\sigma)$ for each family of clusters (eq 3):

$$
\sigma^{2}=\left(P_{i}-P_{b}\right)^{2}
$$

where $\sigma^{2}$ is the variance of the normalized experimental intensities $\left(P_{i}\right)$ of the particular cluster ions versus the intensities of the clusters calculated from the binomial distribution $\left(P_{b}\right)$. Positive and negative signs were assigned to the calculated values based on the shape of the cluster population compared to the statistical prediction. (The qualitative procedure used was that illustrated ${ }^{\circ}$ in $^{\circ}$ the ${ }^{\circ}$ discussion $^{\circ}$ above $^{\circ}$ of ${ }^{\circ}$ the $^{\circ}$ data $^{\circ}$ for $^{\circ}$ Figure $^{\circ} 3$; homochiral preference was assigned a positive $\sigma$ value and vice versa.) The standard deviations so calculated $(\sigma)$ are shown as the chiral preferences on the y-axes in Figure 4 .

A remarkable feature of the serine tetramers is that the chiral preference associated with their formation follows a well-defined trend, which depends on the cation size: tetrameric adducts with $\mathrm{H}^{+}, \mathrm{Li}^{+}$, and $\mathrm{Na}^{+}$ are formed with little chiral effect (a slight preference for heterochirality), whereas the larger cations $\mathrm{K}^{+}, \mathrm{Rb}^{+}$, and $\mathrm{Cs}^{+}$yield serine tetramers that display a strong preference for homochirality. Thus, $\mathrm{K}^{+}$represents a cation threshold size that allows the transition from nonchiroselective to chiroselective formation of serine tetramers. ${ }^{\circ}$ Note $^{\circ}$ too $^{\circ}$ that $^{\circ}$ as $^{\circ}$ shown $^{\circ}$ in $^{\circ}$ Figure $^{\circ} 2 a^{\circ}{ }^{\circ}$ the transition from sodium to potassium corresponds to the largest difference in the magic number factor among the serine tetramers.

Tandem mass spectrometry. Tandem mass spectrometry was employed to obtain additional structural information on the alkali metal-cationized serine tetramers. The (a)

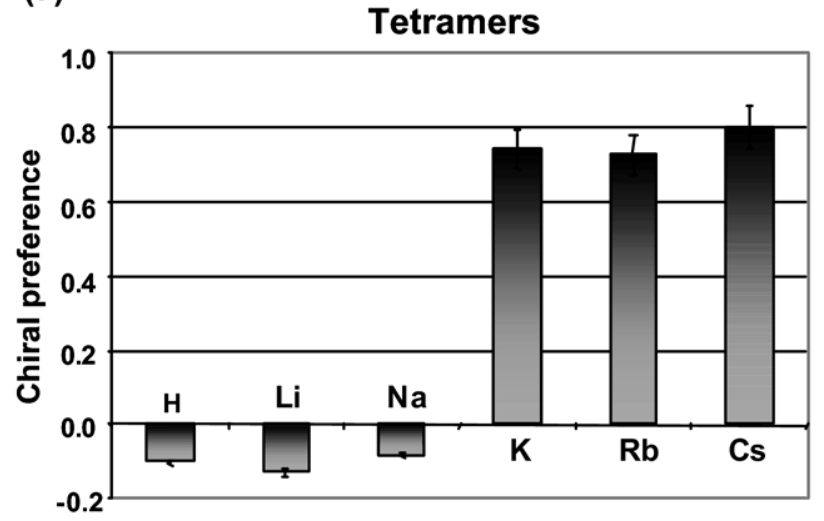

(c)

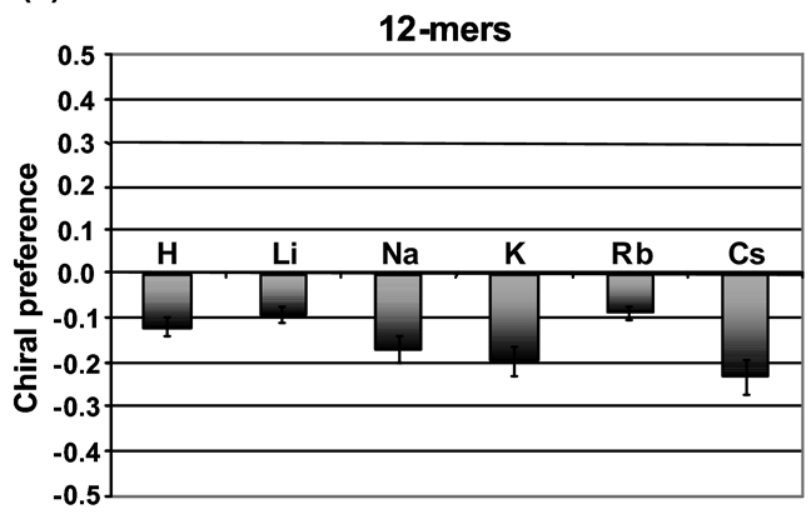

(b)

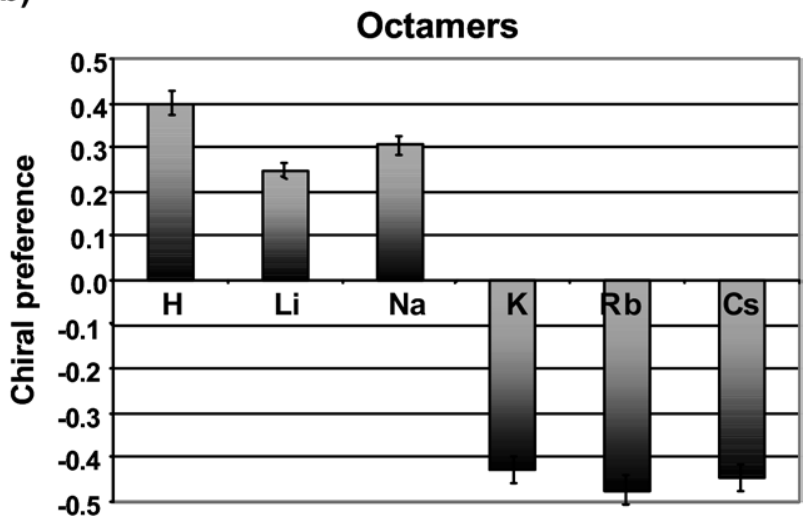

(d)

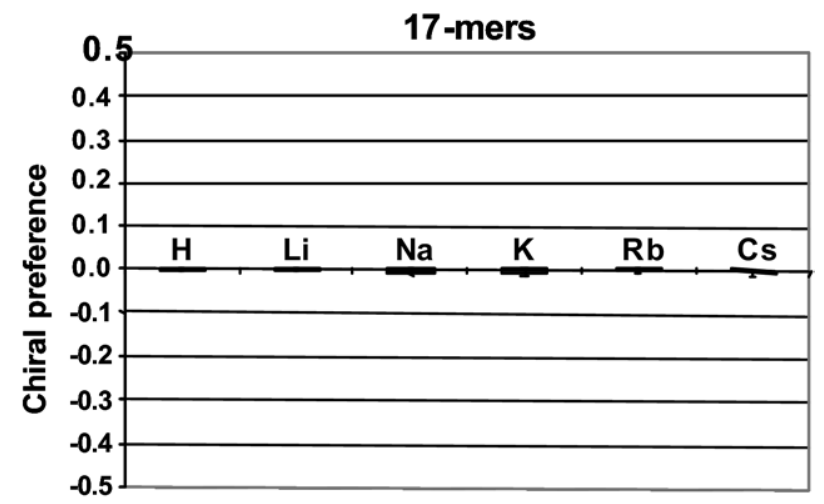

Figure 4. Chiral preference calculated for serine tetramers, octamers, dodecamers, and heptadecamers, formed from a solution containing $2,3,3-\mathrm{d}_{3}$-L-serine $(5 \mathrm{mM})$, D-serine $(5 \mathrm{mM})$, and $2 \%$ of acetic acid or $0.25 \mathrm{mM}$ salt of the cation of interest. (a) $\left(\mathrm{Ser}_{4}+\mathrm{C}\right)^{+},(\mathbf{b})\left(\mathrm{Ser}_{8}+\mathrm{C}\right)^{+}$, (c) $\left(\mathrm{Ser}_{12}+\mathrm{C}\right)^{+}$, and (d) $\left(\mathrm{Ser}_{17}+2 \mathrm{C}\right)^{+2} ; \mathrm{C}=\mathrm{H}, \mathrm{Li}, \mathrm{Na}, \mathrm{K}, \mathrm{Rb}$, or $\mathrm{Cs}$. The y-axis shows a measure of the preference for homochirality/heterochirality as opposed to a statistical distribution of L- and D-enantiomers within the cluster. Positive numbers indicate a preference for homochirality, negative numbers a preference for heterochirality. The values were calculated as described in the text and are much more reliable for the tetramer and octamer than for the larger cations. 
fragmentation patterns of serine tetramers cationized by sodium, potassium, rubidium, and cesium were evaluated as a function of collision energy in collisioninduced $^{\circ}$ dissociation $^{\circ}$ (CID) ${ }^{\circ}$ experiments $^{\circ}$ (Figure $^{\circ} 5$ ). These data allow a qualitative comparison of the energy required to dissociate the precursor ions, as well as the preferred dissociation channels for the tetramers of interest. Note that some clusters dissociate so readily that this occurs upon isolation in the linear ion trap. This $^{\circ}$ can $^{\circ}$ be $^{\circ}$ seen $^{\circ}$ in $^{\circ}{ }^{\circ}$ igure ${ }^{\circ} 5 a,{ }^{\circ}$ which ${ }^{\circ}$ reveals ${ }^{\circ}$ that ${ }^{\circ}$ about $50 \%$ of the $\left(\mathrm{Ser}_{4}+\mathrm{Na}\right)^{+}$ion population does not survive the isolation step ( $0 \%$ relative collision energy). The low collision ${ }^{\circ}$ energy $^{\circ}$ tetramer $^{\circ}$ data $\left.^{\circ}\left(\text { Figure }^{\circ} 5\right)^{\circ}\right)^{\circ}$ agrees $^{\circ}$ quali- $^{-}$ tatively with the cluster stability trend previously given for ${ }^{\circ}$ the ${ }^{\circ}$ tetramers ${ }^{\circ}{ }^{\circ}{ }^{\circ}$ Figure $^{\circ} 2 \mathrm{a} ;{ }^{\circ}$ both ${ }^{\circ}$ results $^{\circ}$ suggest $^{\circ}$ that the sodiated adduct is less stable than $\left(\mathrm{Ser}_{4}+\mathrm{K}\right)^{+}$, $\left(\mathrm{Ser}_{4}+\mathrm{Rb}\right)^{+}$and $\left(\mathrm{Ser}_{4}+\mathrm{Cs}\right)^{+}$. As the collision energy is increased however, dissociation of the mass-selected tetramers increases sharply at $\sim 10 \%$ relative collision energy for each of alkali metal adducts. The differences in initial stability of the $\mathrm{Na}^{+}$and $\mathrm{K}^{+}$clusters are consistent with the structural differences already in- voked, although the situation might be more complex with minor forms of each cluster likely also being present and helping to account the similarity in trends at higher collision energy. In the case of cesium tetramer about $20 \%$ of the initial population remains undissociated in the ion trap, even when the collision energy is increased to $50 \%$. Note too that in case of the rubidium tetramer, about $85 \%$ of the population undergoes dissociation at $10 \%$ relative collision energy but $15 \%$ remains undissociated. These results suggest the existence of two tetrameric $\mathrm{Cs}^{+}$and $\mathrm{Rb}^{+}$isomers of different relative stability. The difference in the stability may be due to the localization of the metal ion in the cluster structure; a tentative suggestion is that one is localized on the tetramer periphery and in the other case, the cation is localized in its interior.

If one looks carefully at the trimeric fragment ions formed ${ }^{\circ} b^{\circ}$ the $^{\circ} \operatorname{loss}^{\circ}$ of $^{\circ} a^{\circ}$ neutral ${ }^{\circ}$ serine $^{\circ}\left(\right.$ Figure $\left.^{\circ} 5 b\right)$, , it $^{\circ}$ is possible to distinguish the fragmentation of the sodiated tetrameric adduct from that of the tetrameric adducts of the larger alkalis. The normalized intensity of the sodiated trimeric fragment, $\left(\mathrm{Ser}_{3}+\mathrm{Na}\right)^{+}$, decays (a)

\section{Precursor ions (serine tetramers)}

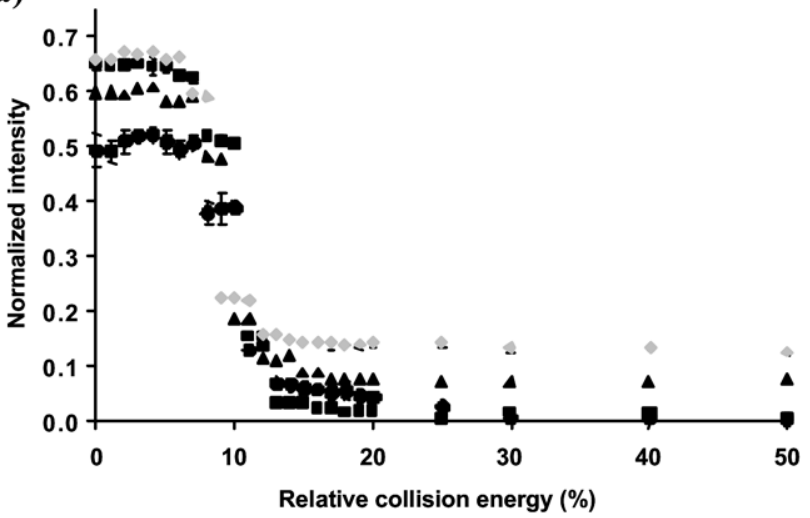

(c)

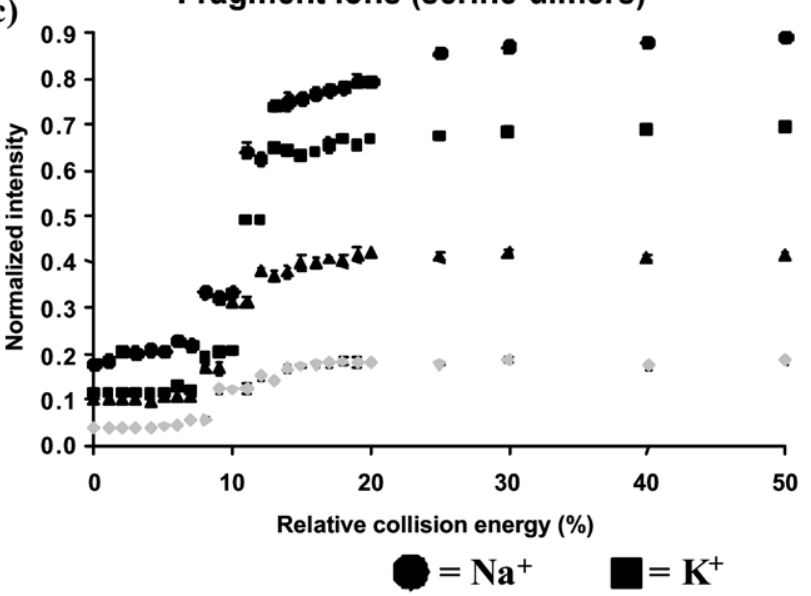

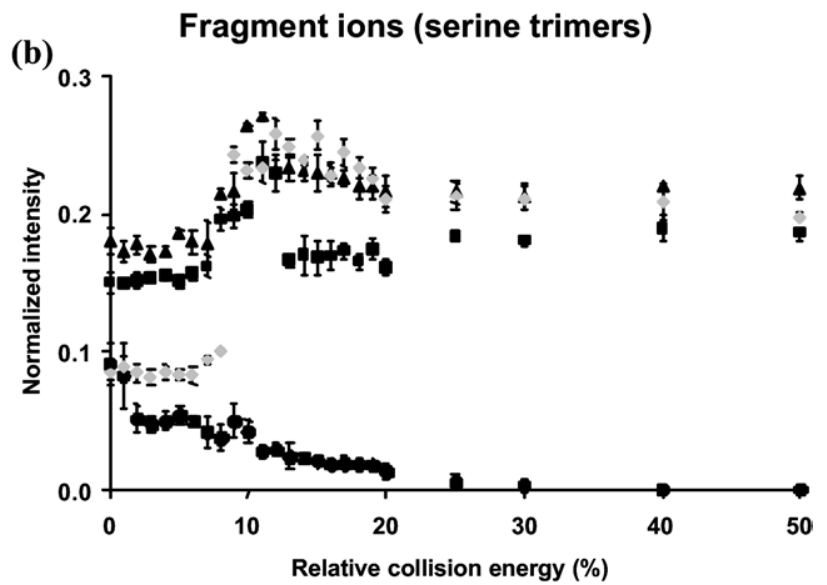

(d)

Fragment ions (serine monomers)

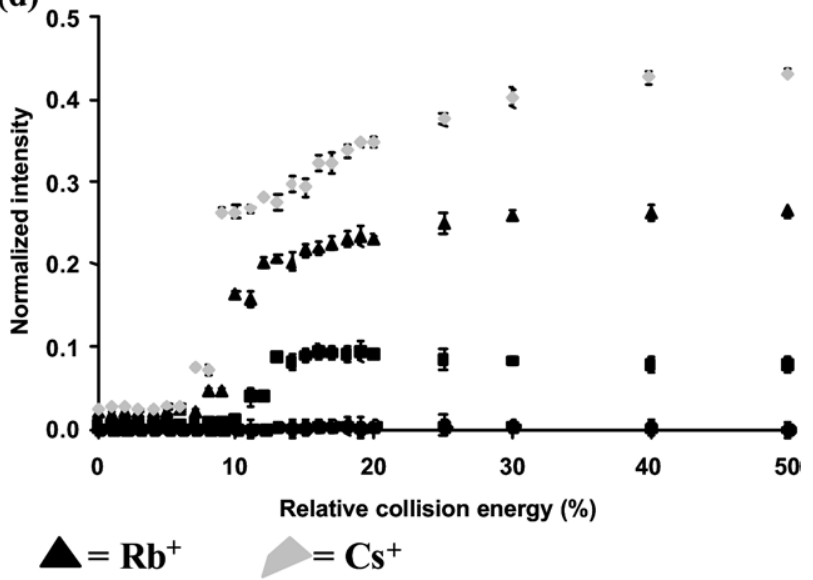

Figure 5. Fragmentation signature of serine tetramers, $\left(\mathrm{Ser}_{4}+\mathrm{C}\right)^{+}$, cationized by alkali metals. The plots show the signal intensity of (a) precursor ions $\left(\mathrm{Ser}_{4}+\mathrm{C}\right)^{+}$and the respective fragment ions (b) $\left(\mathrm{Ser}_{3}+\mathrm{C}\right)^{+}$(c) $\left(\mathrm{Ser}_{2}+\mathrm{C}\right)^{+}$, and $(\mathbf{d})\left(\mathrm{Ser}_{1}+\mathrm{C}\right)^{+}$as a function of collision energy in the MS/MS experiment. Normalization is relative to the pre-isolation ion abundance. 
approximately exponentially as the collision energy is increased. On the other hand, the normalized intensities of the fragment ions $\left(\mathrm{Ser}_{3}+\mathrm{K}\right)^{+},\left(\mathrm{Ser}_{3}+\mathrm{Rb}\right)^{+}$, and $\left(\mathrm{Ser}_{3}+\mathrm{Cs}\right)^{+}$increase, reaching maxima at a relative collision energy of $\sim 10 \%$. This suggests that the tetramers with the larger cations, i.e., $\left(\mathrm{Ser}_{4}+\mathrm{K}\right)^{+},\left(\mathrm{Ser}_{4}+\mathrm{Rb}\right)^{+}$, and $\left(\mathrm{Ser}_{4}+\mathrm{Cs}\right)^{+}$, preferentially fragment by the loss of a molecule of neutral serine, whereas the sodiated tetrameric adduct is more likely to dissociate by loss of a

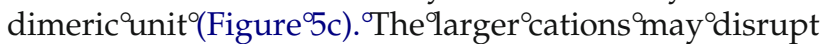
the noncovalent interactions between the serines in the tetramers, accounting for the observed result. This particular hypothesis is supported by the trends shown in $^{\circ}$ Figure $^{\circ} 5 \mathrm{~d}^{\circ}$ for ${ }^{\circ}$ the ${ }^{\circ}$ normalized ${ }^{\circ}$ intensities ${ }^{\circ}$ of $^{\circ}$ mono- $^{-}$ meric fragments: $(\text { Ser }+\mathrm{Cs})^{+}>(\text {Ser }+\mathrm{Rb})^{+}>(\text {Ser }+\mathrm{K})^{+}>$ $(\mathrm{Ser}+\mathrm{Na})^{+}$. However, it must be noted that the differences in the alkali metal cation affinities for monomeric (neutral) serine may also contribute to the observed result. Note also that the opposite result is obtained for the dimeric fragments (Figure $5 \mathrm{c}):\left(\mathrm{Ser}_{2}+\mathrm{Na}\right)^{+}>\left(\mathrm{Ser}_{2}+\mathrm{K}\right)^{+}>$ $\left(\mathrm{Ser}_{2}+\mathrm{Rb}\right)^{+}>\left(\mathrm{Ser}_{2}+\mathrm{Cs}\right)^{+}$; therefore sodium appears to better stabilize dimeric subunits inside the tetramers. It is noteworthy that the existence of two tetrameric $\mathrm{Cs}^{+}$ isomers of different relative stability was proposed. The less stable one dissociates with favored loss of a neutral serine molecule whereas the dissociation pathway of the more stable one remains unclear.

\section{Serine Octamers}

The protonated serine octamer is known to be a stable magic-number cluster through experiments involving electrospray ${ }^{\circ}$ ionization $^{\circ}(\mathrm{ESI})^{\circ}[37-41]^{\circ}$ and $^{\circ}$ related $^{\circ}$ techniques ${ }^{\circ}\left[29^{\circ}-34\right] . .^{\circ}$ Its $^{\circ}$ remarkably $^{\circ}$ strong $^{\circ}$ preference $^{\circ}$ for homochirality ${ }^{\circ}$ led $^{\circ}$ to $^{\circ} a^{\circ}$ series $^{\circ}$ of ${ }^{\circ}$ experiments $\left[38^{\circ}-44,{ }^{\circ} 46\right]$ that engendered the proposal that the serine octamer has $^{\circ} \mathrm{a}^{\circ}$ special $^{\circ}$ role $^{\circ}$ in ${ }^{\circ}$ homochirogenesis ${ }^{\circ}\left[37,{ }^{\circ} 63\right]$.

The sonic spray spectrum of a $10 \mathrm{mM}$ solution of serine sprayed from 50:50 methanol/water mixture containing ${ }^{\circ}$ the $^{\circ}$ cations $^{\circ}$ of $^{\circ}$ interest $^{\circ}$ is ${ }^{\circ}$ shown $^{\circ}$ in ${ }^{\circ}$ Figure $^{\circ} 1$. The relative abundances of these magic number clusters strongly depend on cation size. The absolute abundances of the magic number clusters are found to correlate with the size of the alkali metal cation (Figure ${ }^{\circ}$ ).

Chiral effects. To obtain information about possible chiral preferences associated with the formation of the cationized serine octamers, $\left(\mathrm{Ser}_{8}+\mathrm{C}\right)^{+}$, isotopically labeled serine $\left(2,3,3-\mathrm{d}_{3}\right.$-L-serine $)$ was used to make $10 \mathrm{mM}$ solutions of racemic serine ( $5 \mathrm{mM}$ D-serine, 105

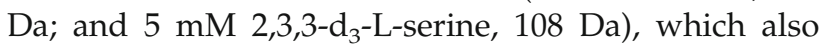
contained a salt of the particular metal cation. Sonic spray mass spectra of these samples were used to study the chiral preferences occurring in the formation of serine ${ }^{\circ}$ octamers ${ }^{\circ}$ cationized $^{\circ}$ by $^{\circ}$ alkali ${ }^{\circ}$ metals. ${ }^{\circ}$ Figure $^{\circ} 4 \mathrm{~b}$ compares the chiral preferences associated with the formation of serine octamers in the presence of particular cations, as revealed by isotope labeling.
Racemic solutions of D-serine and 2,3,3- $\mathrm{d}_{3}-\mathrm{L}$-serine containing $\mathrm{H}^{+}, \mathrm{Li}^{+}$, or $\mathrm{Na}^{+}$resulted in mostly homochiral octamers, in agreement with previous observations $^{\circ}[43] .^{\circ}$ That $^{\circ}$ is, ${ }^{\circ}$ the $^{\circ}$ data $^{\circ}$ show $^{\circ}$ the $^{\circ}$ expected $^{\circ}$ strong homochiral preference for the $\mathrm{H}^{+}, \mathrm{Li}^{+}$, or $\mathrm{Na}^{+}$octamers of serine. This situation is completely inverted for the $\mathrm{K}^{+}, \mathrm{Cs}^{+}$, and $\mathrm{Rb}^{+}$cations, as shown by the sharp break in the chiral preference from homochirality to heterochirality $^{\circ}$ in $^{\circ}$ Figure $^{\circ} 4 \mathrm{~b}^{\circ}$ The $^{\circ}$ data $^{\circ}$ also $^{\circ}$ showed $^{\circ}$ that, ${ }^{\circ}$ in contrast to the well-known behavior of protonated and sodiated $^{\circ}$ serine $^{\circ}$ octamers $^{\circ}\left[38^{\circ}-40,{ }^{\circ} 45\right]^{\circ}{ }^{\circ}$ the ${ }^{\circ}$ octameric adducts formed in the presence of the larger alkali metal cations are preferentially composed of the heterochiral species containing $4 \mathrm{~L}$ and $4 \mathrm{D}$ enantiomers in each molecule. (see Supplementary Material section which can be found in the electronic version of this article).

Tandem mass spectrometry. In an effort to obtain information about the distribution of individual serine enantiomers within the octamers associated with each of the larger alkali metal cations $\mathrm{K}^{+}, \mathrm{Rb}^{+}$, or $\mathrm{Cs}^{+}$, the entire distribution of cluster ions obtained from the isotopically-labeled racemic mixture was isolated in the ion trap and collisionally activated to induce fragmentation. Tandem mass spectra showed that the racemic octamers formed in the presence of potassium, rubidium and cesium cations dissociate to form homochiral tetramers! An example of this unprecedented behavior ${ }^{\circ}$ in ${ }^{\circ}$ the ${ }^{\circ}$ case $^{\circ}$ of ${ }^{\circ} \mathrm{K}^{+}{ }^{\circ}$ is ${ }^{\circ}$ shown ${ }^{\circ}$ in ${ }^{\circ}$ Figure $^{\circ} 6,{ }^{\circ}$ where the tetrameric product ions have a very similar isotopic distribution to that seen for the simple tetramers in Figure $3 \mathrm{~b}$. The ${ }^{\text {trimeric }}{ }^{\text {products }}$ follow the tetramers in chiral pattern while the distributions of multiplycharged clusters observed at $\mathrm{m} / \mathrm{z} 600$ to 800 correspond to fragments of $\left(\mathrm{Ser}_{16}+2 \mathrm{~K}\right)^{+2}$, which are isolated together with $\left(\operatorname{Ser}_{8}+\mathrm{K}\right)^{+}$because they have identical mass-to-charge ratios. The observation of homochiral tetrameric ${ }^{\circ}$ fragments $^{\circ}\left(\text { Figure }^{\circ} 6 \mathrm{c}\right)^{\circ}$ confirms $^{\circ}$ that ${ }^{\circ}$ even though $\mathrm{K}_{-}, \mathrm{Rb}-$, and $\mathrm{Cs}-\mathrm{cationized}$ serine octamers appear to be formed from equal numbers of D- and L-serines, i.e., with heterochiral selectivity, serine enantiomers are positioned within these structures so as to form homochiral subunits $\left(\mathrm{Ser}_{4}\right)$ inside the cluster.

It is important to note that the octamers cationized by $\mathrm{K}^{+}, \mathrm{Rb}^{+}$, or $\mathrm{Cs}^{+}$are very different from those formed with smaller cations like $\mathrm{H}^{+}, \mathrm{Li}^{+}$, and $\mathrm{Na}^{+}$; the latter octamers $^{\circ}$ are $^{\circ}$ formed $^{\circ}$ with $^{\circ}$ strong $^{\circ}$ chiral $^{\circ}$ selectivity ${ }^{\circ}[38$, 41] ${ }^{\circ}$ while ${ }^{\circ}$ the ${ }^{\circ}$ former ${ }^{\circ}$ octamers ${ }^{\circ}$ show $^{\circ}$ strong ${ }^{\circ}$ heterochiral preference $^{\circ}\left(\right.$ Figure $\left.^{\circ} 4 \mathrm{~b}\right)$; $^{\circ}$ the $^{\circ}$ strongly $^{\circ}$ favored ${ }^{\circ}$ cluster $^{\circ}$ of chiral composition $4 \mathrm{~L}: 4 \mathrm{D}$ is itself nominally a racemic entity but is composed of homochiral tetrameric units. Adding to the complexity of the situation, this ion and the associated set of diastereomeric heavy alkalicationized serine octamers is formed by a process with a strong heterochiral preference. Thus $\mathrm{K}^{+}$represents a cation threshold size that locates the transition between the two very different homochiral systems of the amino acid serine. Furthermore, the tetramers are not the only 
(a)

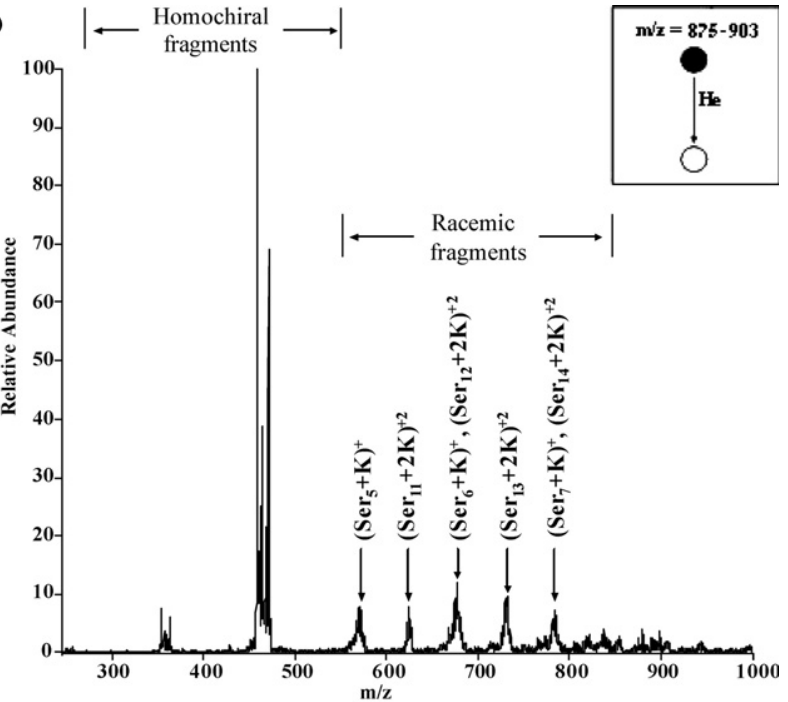

(b)

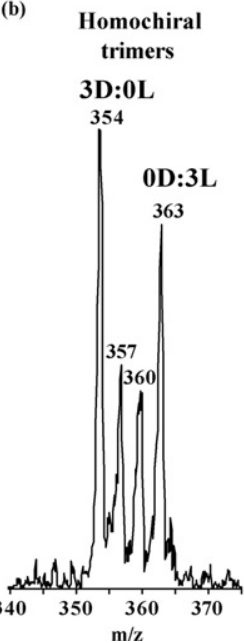

(c) Homochiral tetramers 4D:0L

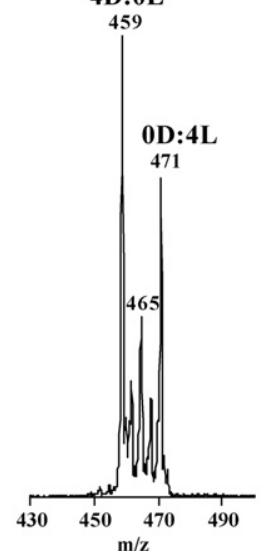

(d) tridecamers 7D:6L $730.56 \mathrm{D}: 7 \mathrm{~L}$

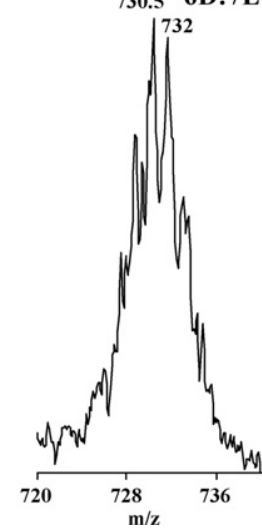

Figure 6. (a) Isotope labeling tandem mass spectrum of the entire distribution of $\left(\mathrm{Ser}_{8}+\mathrm{K}\right)^{+}$ions and also isobaric $\left(\mathrm{Ser}_{16}+2 \mathrm{~K}\right)^{+2}$, formed from a solution containing $2,3,3-\mathrm{d}_{3}-\mathrm{L}$-serine $(5 \mathrm{mM})$, D-serine $(5 \mathrm{mM})$, and $0.25 \mathrm{mM} \mathrm{KCl}$. Expanded regions of the spectrum (b), (c), and (d) show the largely homochiral trimer, tetramer, and racemic tridecamer fragments, respectively. The data demonstrate that even though the distribution of octamers $\left(\mathrm{Ser}_{8}+\mathrm{K}\right)^{+}$is centered at the racemic cluster (4D:4L), they are composed of homochiral tetrameric subunits. The trimers are the products of tetramer dissociation and share their homochirality.

homochiral clusters observed in mixtures of serine and the alkali metals $\mathrm{K}^{+}, \mathrm{Rb}^{+}$, and $\mathrm{Cs}^{+}$; homochiral trimeric cluster ions are also detected. For example, a typical single-stage mass spectrum of a racemic mixture of serine (L-enantiomer, isotopically labeled) and rubidium shows the following relative abundances for the distribution of trimers: 3D:0L $(\mathrm{m} / \mathrm{z} 400,100 \%), 2 \mathrm{D}: 1 \mathrm{~L}$ $(\mathrm{m} / \mathrm{z} 403,37 \%), 1 \mathrm{D}: 2 \mathrm{~L}(\mathrm{~m} / \mathrm{z} 406,29 \%)$, and 0D:3L $(\mathrm{m} / \mathrm{z}$ $409,91 \%)$. However, these clusters are likely to be related to the homochiral tetramers, since one of the preferred fragmentation pathways observed in the tandem mass spectra of serine tetramers corresponds to the loss of a neutral serine, yielding trimeric fragments.
Figure ${ }^{\circ} 6 b^{\circ}$ also ${ }^{\circ}$ shows ${ }^{\circ}$ that ${ }^{\text {h }}$ omochiral ${ }^{\circ}$ serine ${ }^{\circ}$ trimers ${ }^{\circ}$ are obtained from the dissociation of larger aggregates. The data suggests that the homochiral serine trimers observed in the singly-stage mass spectra of serine $/ \mathrm{K}^{+}$, serine $/ \mathrm{Rb}^{+}$and serine $/ \mathrm{Cs}^{+}$mixtures simply originate from the dissociation of homochiral tetramers.

\section{Other Serine/Alkali Metal Clusters}

The relative abundances of the 12-mers and 17-mers, with respect to the alkali-metal-cationized serine octamer, increase continuously with cation size, as shown in ${ }^{\circ}$ Figure ${ }^{\circ}$, eventually ${ }^{\circ}$ exceeding ${ }^{\circ}$ those ${ }^{\circ}$ of ${ }^{\circ}$ the ${ }^{\circ}$ octameric adduct for $\mathrm{C}=\mathrm{Rb}^{+}, \mathrm{Cs}^{+}$. Under the conditions of this experiment ${ }^{\circ}$ (Figure 1$)$, ${ }^{\circ}$ various ${ }^{\circ}$ serine $/$ alkali $^{\circ}$ metal $^{\circ}$ Clus- $^{\circ}$ ters were found to have higher relative abundances than their protonated analogs. This is the case of some larger serine aggregates such as dodecamers and doubly-charged 17-mers, when cationized by rubidium or cesium. The unique mass-to-charge ratios of the ions $\left(\operatorname{Ser}_{17}+2 \mathrm{C}\right)^{+2}$, which do not match the $m / z$ values of any singly-charged adduct, make it easy to identify the charge state of these clusters as +2 . However, in the case of ions of the type $\left(\mathrm{Ser}_{12}+\mathrm{C}\right)^{+}$, contributions from multiply-charged clusters $\left(\mathrm{Ser}_{24}+2 \mathrm{C}\right)^{+2},\left(\mathrm{Ser}_{36}+3 \mathrm{C}\right)^{+3}$, etc. cannot be determined from the data shown in Figure $^{\circ} 1,{ }^{\circ}$ since $^{\circ}$ the ${ }^{\circ}$ maximum ${ }^{\circ}$ achievable ${ }^{\circ}$ resolution ${ }^{\circ}$ in the ion trap instrument is insufficient to distinguish signals corresponding to species containing naturalheavy isotopes (i.e., ${ }^{13} \mathrm{C}$ ). The result of an experiment that does allow the differentiation of these charge states (cation labeling) is described next.

Charge states of adducts. To confirm or eliminate contributions from multiply-charged ions to the signal at $m / z 1345^{\circ}$ in $^{\circ}$ Figure $^{\circ} 1$ e, $^{\circ}$ i.e.,${ }^{\circ}\left(\operatorname{Ser}_{12}+\mathrm{C}\right)^{+}$, a mixture containing serine and both the cations $\left(\mathrm{Rb}^{+}\right.$and $\left.\mathrm{Cs}^{+}\right)$that best stabilize this cluster was analyzed. If multiplycharged species are present, signals corresponding to ions containing both cations should arise. For example, $\left(\mathrm{Ser}_{24}+\mathrm{Rb}+\mathrm{Cs}\right)^{+2}$ has a unique mass-to-charge ratio, which would distinguish it from $\left(\mathrm{Ser}_{12}+\mathrm{Rb}\right)^{+}$ and $\left(\mathrm{Ser}_{12}+\mathrm{Cs}\right)^{+}$ions. The results of the SSI-MS analysis of a L-serine $/ \mathrm{RbCl} / \mathrm{CsCl}$ mixture, shown in Figure ${ }^{\circ}$, indicate ${ }^{\circ}$ that ${ }^{\circ}$ only ${ }^{\circ}$ singly-charged ${ }^{\circ} 12$-mers ${ }^{\circ}$ are present, since $\left(\mathrm{Ser}_{24}+\mathrm{Rb}+\mathrm{Cs}\right)^{+2}$ ions were not detected. The $^{\circ}$ same $^{\circ}$ mass $^{\circ}$ spectrum $^{\circ}\left(\text { Figure }^{\circ} 7\right)^{\circ}$ also $^{\circ}$ shows $^{\circ}$ a distribution of signals (from $m / z 978$ to $m / z$ 1025), which correspond to doubly-charged 17-mers. Note that the distribution is centered at the $\mathrm{m} / \mathrm{z} 1001$ signal, $\left(\mathrm{Ser}_{17}+\mathrm{Rb}+\mathrm{Cs}\right)^{+2}$ ions, which is expected for "pure" doubly-charged ions without contributions from their singly-charged counterparts.

The fact that tetramers, octamers, and dodecamers of serine cationized by alkali-metals are observed with remarkably high abundance suggests that the dodecamers, $\left(\mathrm{Ser}_{12}+\mathrm{Rb}\right)^{+}$and $\left(\mathrm{Ser}_{12}+\mathrm{Cs}\right)^{+}$, might be related to the smaller serine aggregates. These higher clusters might be derivatives of octamers and/or tetramers; for 


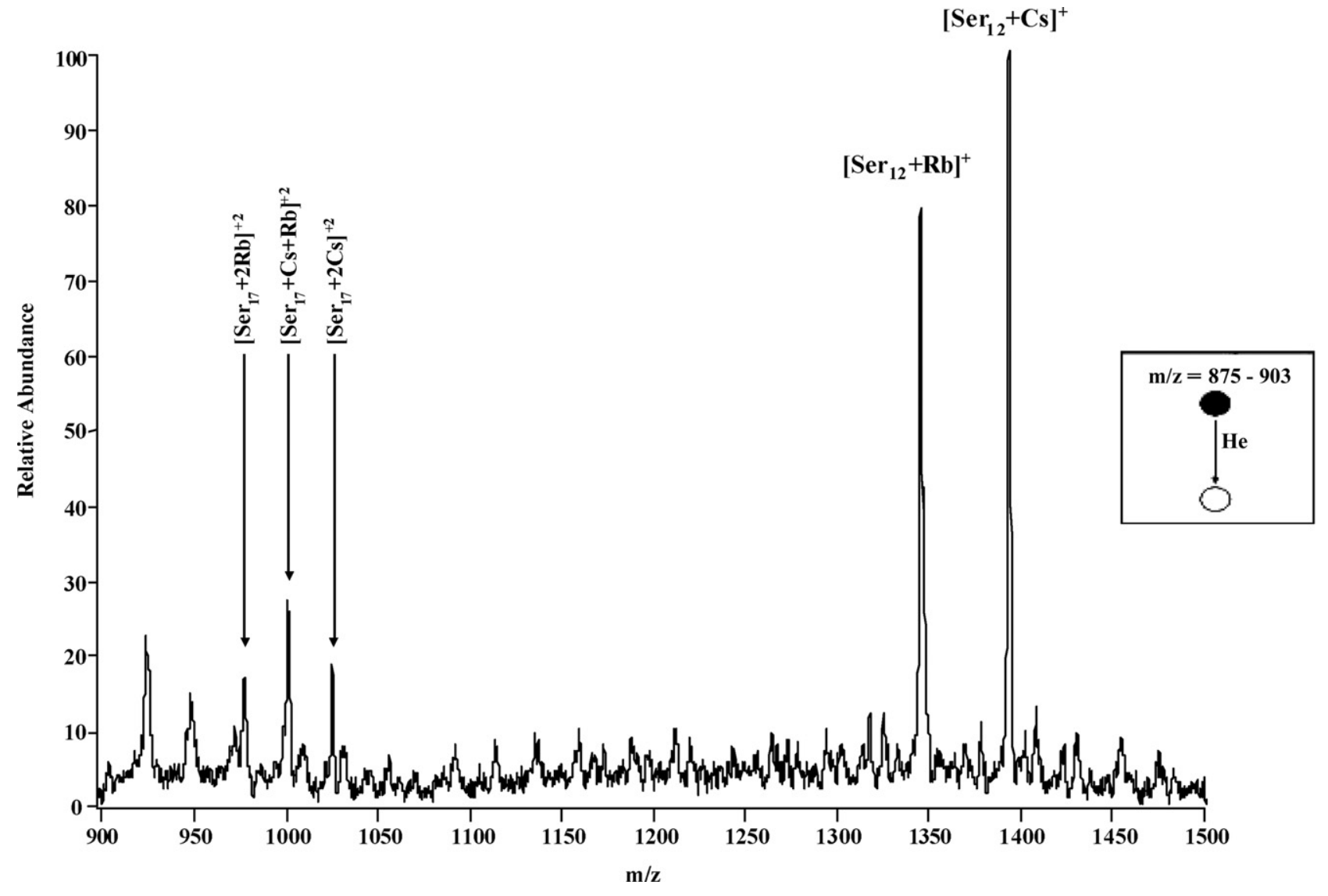

Figure 7. SSI-MS of a solution containing $8.0 \mathrm{mM}$ L-serine, $0.25 \mathrm{mM} \mathrm{RbCl}$, and $0.25 \mathrm{mM} \mathrm{CsCl}$. Note the absence of $\left(\mathrm{Ser}_{24}+\mathrm{Rb}+\mathrm{Cs}\right)^{+2}$ clusters, which implies that only singly-charged 12 -mers are present.

example, they could exist as conglomerates such as $\left(\mathrm{Ser}_{4}+\mathrm{Ser}_{8}+\mathrm{C}\right)^{+}$. This hypothesis was tested by using the $\mathrm{MS}^{\mathrm{n}}$ capabilities of the quadrupole ion trap mass spectrometer to compare tandem mass spectra $\left(\mathrm{MS}^{2}\right.$ and $\mathrm{MS}^{3}$ of the 8 -mers and 12-mers.

$M S^{n}$ experiments. After characterizing the charge state of each of the magic number clusters as just described, tandem mass spectrometry was employed to obtain structural information on these species. The sonic spray tandem mass spectrum of the ion $\left(\mathrm{Ser}_{12}+\mathrm{Rb}\right)^{+}$is shown in $^{\circ}$ Figure ${ }^{\circ} 8$. ${ }^{\circ}$ Note $^{\circ}$ that ${ }^{\circ}$ the ${ }^{\circ}$ preferred ${ }^{\circ}$ dissociation $^{\circ}$ channel is the loss of a neutral tetramer to form the octameric fragment $\left(\mathrm{Ser}_{8}+\mathrm{Rb}\right)^{+}$. This data supports the above hypothesis that serine dodecamers cationized by the larger alkali metals, e.g., $\left(\mathrm{Ser}_{12}+\mathrm{Rb}\right)^{+}$, are composed of smaller cluster units, specifically the tetramer and octamer. Regardless of how the octameric fragment seen

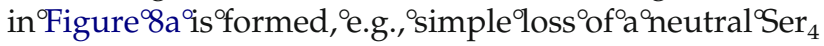
or with rearrangement, the data suggest that the Rbcationized serine octamer seen in the single-stage mass spectra is the same ion that originates from fragmentation of the precursor $\left(\operatorname{Ser}_{12}+\mathrm{Rb}\right)^{+}$in the MS/MS data. This hypothesis was confirmed by comparing the fragmentation pattern of the fragment ion $\left(\mathrm{Ser}_{8}+\mathrm{Rb}\right)^{+}$derived in a $\mathrm{MS}^{3}$ experiment from the precursor $\left(\mathrm{Ser}_{12}+\mathrm{Rb}\right)^{+}(\mathrm{m} / \mathrm{z}$ 1345) to the tandem mass spectrum $\left(\mathrm{MS}^{2}\right.$ of the Rb-cationized serine octamer (see Figure $\left.{ }^{\circ} 8 \mathrm{~b},{ }^{\circ} \mathrm{C}\right) .{ }^{\circ}{ }^{\circ}$ oth ${ }^{\circ}$ showed ${ }^{\circ}$ almost ${ }^{\circ}$ identical ${ }^{\circ}$ fragmentation behavior. Contributions from $\left(\mathrm{Ser}_{16}+\mathrm{Rb}\right)^{+2}$ are also evident $^{\circ}$ in $^{\circ}$ Figure $^{\circ} 8 c^{\circ}$, since $^{\circ}$ doubly-charged ${ }^{\circ}$ fragment ions at $\mathrm{m} / \mathrm{z} 767$ and $\mathrm{m} / \mathrm{z} 873$ are present. Note that only singly-charged ions are obtained from the precursor ion $\left(\mathrm{Ser}_{12}+\mathrm{Rb}\right)^{+}$. The particular formation of $\left(\mathrm{Ser}_{4}+\mathrm{Rb}\right)^{+}$ fragments ${ }^{\circ}$ seen $^{\circ}$ in ${ }^{\circ}$ Figure $^{\circ} 8 \mathrm{~b},{ }^{\circ} \mathrm{C}^{\circ}{ }^{\circ} \mathrm{Confirms}^{\circ}$ the ${ }^{\circ}$ stability ${ }^{\circ}$ of alkali-metal-cationized serine tetramers and again suggests that they could be the building blocks of the larger serine clusters: the octamers and dodecamers. Octamers and dodecamers of serine cationized by $\mathrm{K}^{+}$and $\mathrm{Cs}^{+}$ undergo collision-induced dissociation in an analogous fashion to $\left(\mathrm{Ser}_{8}+\mathrm{Rb}\right)^{+}$clusters (data not shown). On the other hand, tandem mass spectra showed that the doubly-charged 17-mers fragment by the sequential loss of single neutral serines, which suggest that these clusters do not belong to the family of "metaclusters of tetramers" like the singly-charged octamers and dodecamers.

Chiral effects. The analysis of racemic solutions containing D-serine and 2,3,3- $\mathrm{d}_{3}$-L-serine resulted in distributions of serine units in the 12-mers, which show enhanced intensity for the clusters composed of equal 
(a)

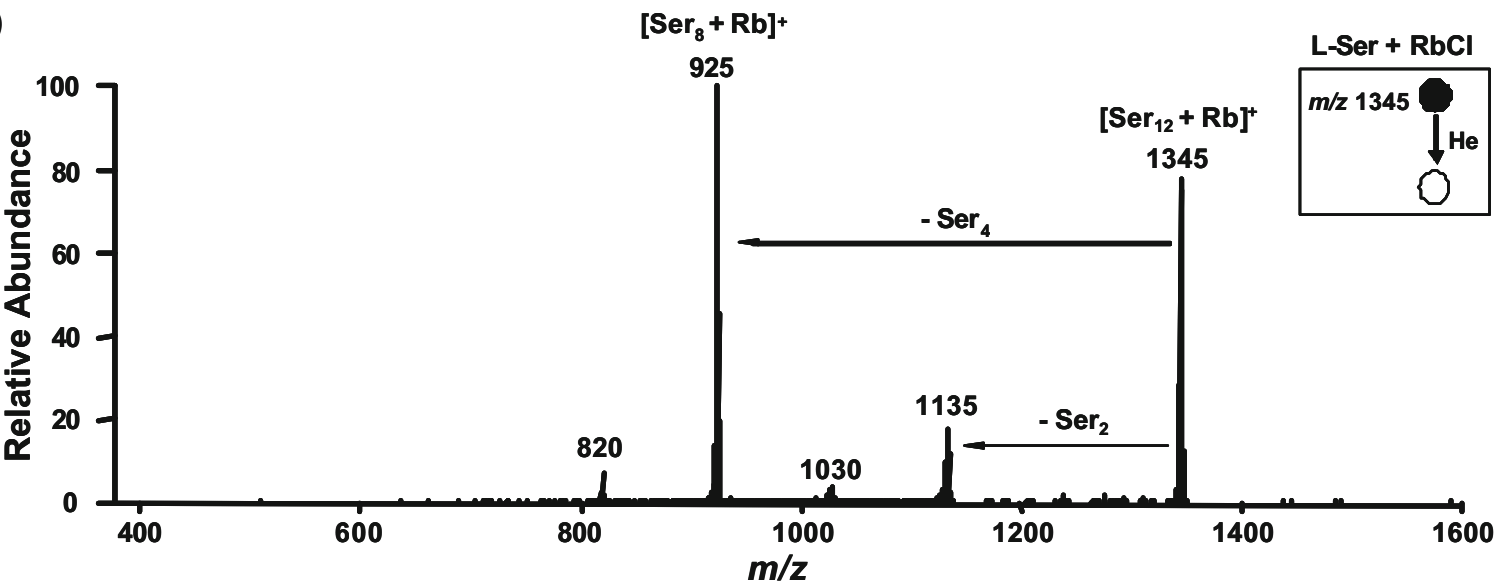

(b)

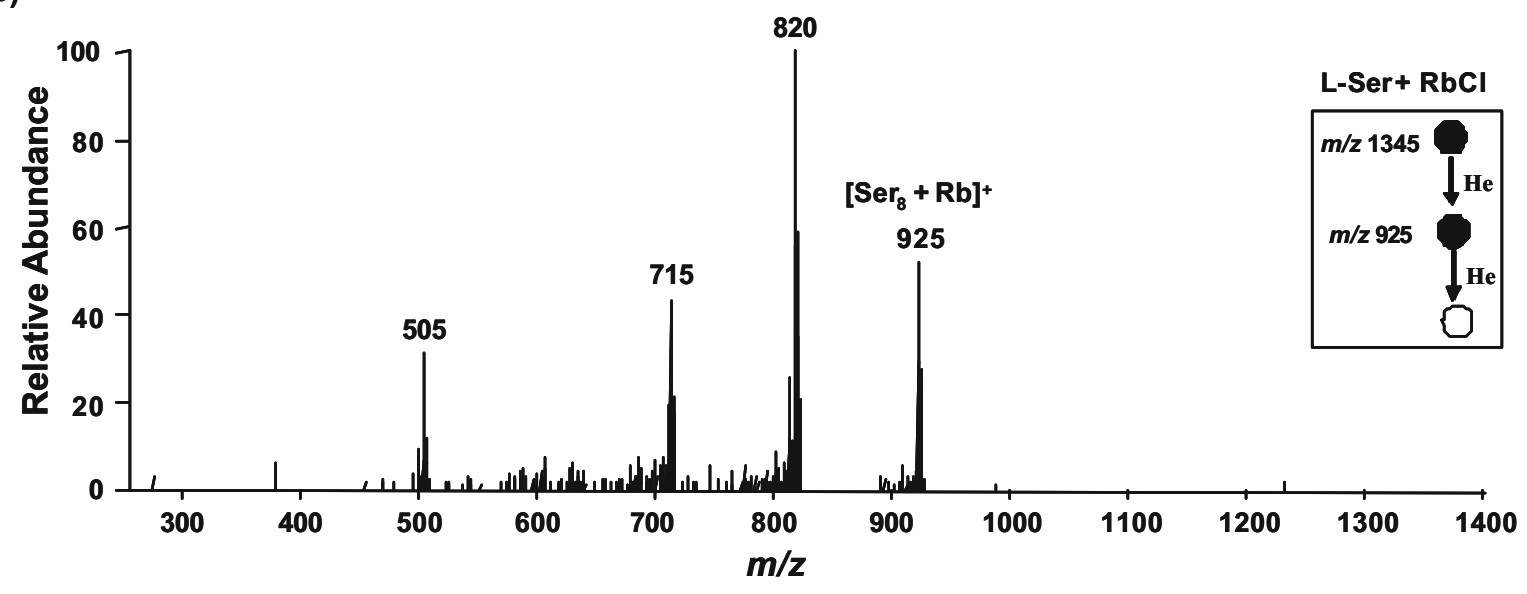

(c)

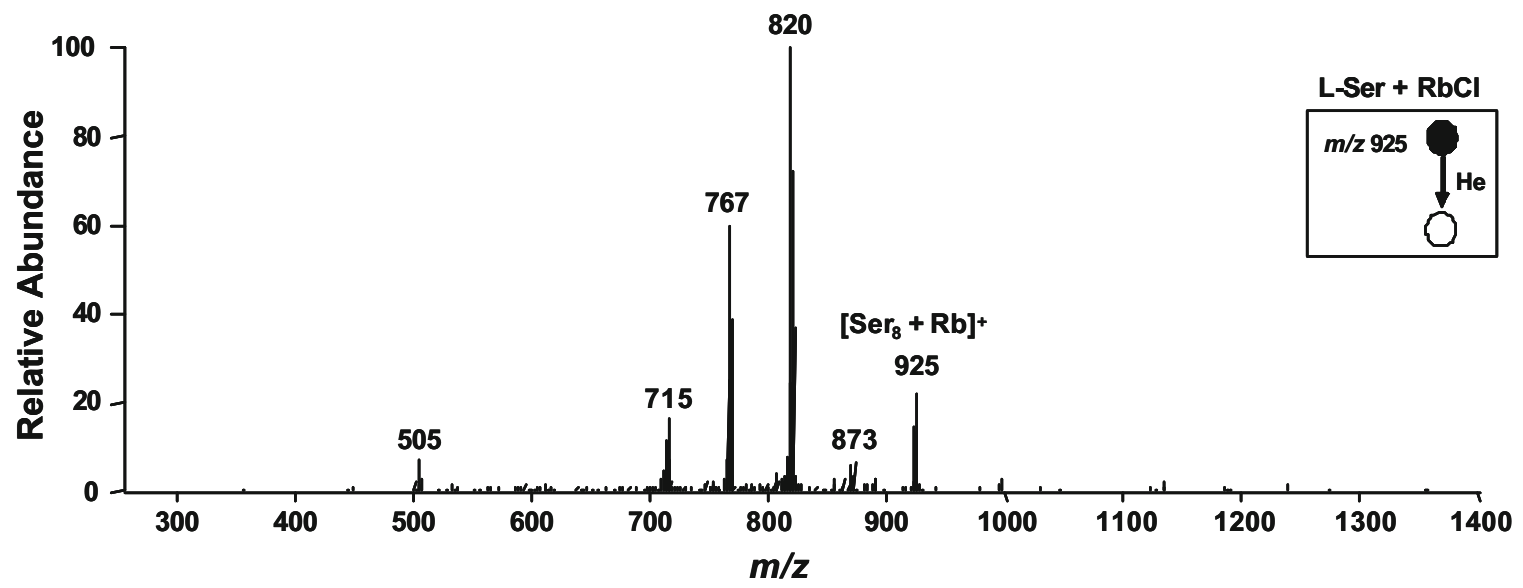

Figure 8. Comparison of $\mathrm{MS}^{\mathrm{n}}$ spectra of a mixture containing serine and rubidium chloride. (a) SSI-MS/MS of the precursor ion $\left(\mathrm{Ser}_{12}+\mathrm{Rb}\right)^{+}$in a L-serine/rubidium chloride mixture. Note that the main fragmentation pathway is the loss of a neutral serine tetramer, which suggests that the ion $\left(\mathrm{Ser}_{12}+\mathrm{Rb}\right)^{+}$is comprised of at least two major units, i.e., $\left(\mathrm{Ser}_{4}+\mathrm{Ser}_{8}+\mathrm{Rb}\right)^{+}$. (b): MS ${ }^{3}$ spectrum of the precursor ion $\left(\mathrm{Ser}_{12}+\mathrm{Rb}\right)^{+}\left(\mathrm{m} / \mathrm{z}\right.$ 1345), fragmenting via $\left(\mathrm{Ser}_{8}+\mathrm{Rb}\right)^{+}\left(\mathrm{m} / \mathrm{z}\right.$ 925). (c): $\mathrm{MS}^{2}$ spectrum of $\left(\mathrm{Ser}_{8}+\mathrm{Rb}\right)^{+}$. The signals at $\mathrm{m} / \mathrm{z} 767$ and $\mathrm{m} / \mathrm{z} 873$ are doubly-charged fragments of multiply-charged precursor ions, $\left(\mathrm{Ser}_{16}+2 \mathrm{Rb}\right)^{+2}$, $\left(\mathrm{Ser}_{24}+3 \mathrm{Rb}\right)^{+3}$, etc. The data suggest that the octameric unit of $\mathrm{Rb}$-cationized 12-mers is identical to the octamer seen in the single-stage spectrum. Data were recorded using (a) $12.0 \%$ collision energy and isolation window of $20 \mathrm{~m} / z$ units (b) $80 \%$ collision energy, and $25 \mathrm{~m} / \mathrm{z}$ units isolation window for the dodecameric precursor ion (signal at $\mathrm{m} / \mathrm{z} 1345$ ) to optimize the signal intensity of the octameric fragment; $10 \%$ collision energy and $25 \mathrm{~m} / \mathrm{z}$ units of isolation window for the octameric precursor ion (signal at $\mathrm{m} / \mathrm{z}$ 925). (c) Collision energy of $10 \%$ and $25 \mathrm{~m} / \mathrm{z}$ units of isolation window for the octameric precursor ion (signal at $\mathrm{m} / \mathrm{z}$ 925). 


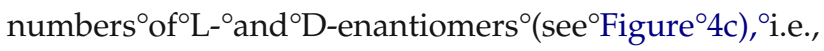
the process displays a heterochiral preference. These results, combined with the tandem mass spectra (e.g., Figures ${ }^{\circ} 6^{\circ}$ and $\left.^{\circ} 7\right)^{\circ}$ suggest $^{\circ}$ that ${ }^{\circ}$ homochiral ${ }^{\circ}$ tetramers ${ }^{\circ}$ of serine (cationized by $\mathrm{K}^{+}, \mathrm{Rb}^{+}$, or $\mathrm{Cs}^{+}$) aggregate further in a chirally blind fashion to form serine dodecamers. Following our hypothesis, we expect and observe a net heterochiral preference in 12-mer formation, especially for $\mathrm{Cs}^{+}$the largest of the cations (see Supplemental material).

\section{Conclusions}

The amino acid serine forms stable clusters of the type $\left(\operatorname{Ser}_{8}+\mathrm{C}\right)^{+},\left(\operatorname{Ser}_{12}+\mathrm{C}\right)^{+}$, and $\left(\operatorname{Ser}_{17}+2 \mathrm{C}\right)^{+2}$ ionized by cations of alkali elements $(\mathrm{C})$. The relative abundances of these magic number clusters strongly depend on cation size; the larger clusters, $\left(\mathrm{Ser}_{12}+\mathrm{C}\right)^{+}$and $\left(\mathrm{Ser}_{17}+2 \mathrm{C}\right)^{+2}$, are preferentially formed with the larger alkali metal cations such as rubidium and cesium. Tandem mass spectrometry results demonstrate that the octamers and dodecamers of serine formed with the alkali metals $\mathrm{K}, \mathrm{Rb}$ and $\mathrm{Cs}$ are composed of smaller tetrameric building blocks. Although these smaller units are formed with strong preference for homochirality, to a first approximation they aggregate further regardless of their handedness giving a net preference for heterochirality in the octamers and dodecamers. It should be noted again that octamers cationized by $\mathrm{K}^{+}$, $\mathrm{Rb}^{+}$, or $\mathrm{Cs}^{+}$are different from those formed with smaller alkali metal cations such as lithium and sodium; the latter octamers are formed with strong homochiral preference 938,41$]$. The ${ }^{\circ}$ ctamers ${ }^{\circ}$ cationized $\mathrm{by} \mathrm{K}^{+}, \mathrm{Rb}^{+}$, or $\mathrm{Cs}^{+}$represent a new type of cluster ion, which is homochiral in its internal subunits. The potassium ion represents the threshold size that sets the transition between the two very different homochiral systems of the amino acid serine.

The two clustering trends of serine uncovered in this study represent two different mechanisms of cluster-ion formation: (1) ionization/adduct formation involving alkali ions with pre-formed neutral clusters of serine and (2) cation-directed clustering. The former seems to occur when serine is sprayed in the presence of the smaller cations: $\mathrm{H}^{+}, \mathrm{Li}^{+}$, or $\mathrm{Na}^{+}$. On the other hand, the metal ions $\mathrm{K}^{+}, \mathrm{Rb}^{+}$, and $\mathrm{Cs}^{+}$appear to direct the formation of clusters which are built around the larger ions.

These observations represent an initial enquiry into a complex structural chemistry. Some of the details of the data are not understood. For example, there is a preference in both the tetramers and the octamers for even numbers of L- and D-serines and against the odd number mixtures. The occurrence of strong heterochiral clustering preferences is one of the most interesting features of this study, such a preference having been reported in only a few previous cases, and even then the effects ${ }^{\circ}$ have ${ }^{\circ}$ been $^{\circ}$ relatively ${ }^{\circ}$ small $^{\circ}[36,050,051,065] .{ }^{\circ}$ Notably, a recent study on the cluster formation of other amino acid, proline, revealed that chirality has a significant impact on the assembly of proline into cluster ions ${ }^{\circ}[65]$.

\section{Acknowledgments}

This work was supported by the National Science Foundation (CHE 04-12,782) and by the U.S. Department of Energy, Office of Basic Energy Sciences (DE-FG02-94ER14470 A8).

\section{References}

1. Hofstadler, S. A.; Griffey, R. H. Analysis of Noncovalent Complexes of DNA and RNA by Mass Spectrometry. Chem. Rev. 2001, 101, 377-390.

2. Borman, S. Quadruplex Proposals. Chem. Eng. News 2002, 80, 36-37.

3. Borman, S. Quadruplex Seen in Human Cells. Chem. Eng. News 2002, 80, 9.

4. Fukushima, K.; Iwahashi, H. 1:1 Complex of Guanine Quartet with Alkali Metal Cations Detected by Electrospray Ionization Mass Spectrometry. Chem. Commun. 2000, 895-896.

5. Freisinger, E.; Schimanski, A.; Lippert, B. Thymine-Metal Ion Interactions: Relevance for Thymine Quartet Structures. J. Biol. Inorg. Chem. 2001, 6, 378-389.

6. Koch, K. J.; Aggerholm, T.; Nanita, S. C.; Cooks, R. G. Clustering of Nucleobases with Alkali Metals Studied by Electrospray Ionization Mass Spectrometry: Implications for Mechanisms of Multistrand DNA Stabilization. J. Mass Spectrom. 2002, 37, 676-686.

7. Tirumala, S.; Davis, J. T. Self-Assembled Ionophores. An Isoguanosine-K+ Octamer. J. Am. Chem. Soc. 1997, 119, 2769-2776.

8. Mezzina, E.; Mariani, P.; Itri, R.; Masiero, S.; Pieraccini, S.; Spada, G. P.; Spinozzi, F.; Davis, J. T.; Gottarelli, G. The Self-Assembly of a Lipophilic Guanosine Nucleoside into Polymeric Columnar Aggregates: The Nucleoside Structure Contains Sufficient Information to Drive the Process Towards a Strikingly Regular Polymer. Chem. Eur. J. 2001, 7, 388-395.

9. Aggerholm, T.; Nanita, S. C.; Koch, K.; Cooks, R. G. Clustering of Nucleosides in the Presence of Alkali Metals. Biologically Relevant Quartets of Guanosine, Deoxyguanosine, and Uridine Observed by Electrospray Ionization Tandem Mass Spectrometry. J. Mass Spectrom. 2003, 38, 87-97

10. Canty, A. J.; Colton, R.; D'Agostino, A.; Traeger, J. C. Positive and Negative Ion Electrospray Mass Spectrometric Studies of Some Amino Acids and Glutathione, and Their Interactions with Alkali Metal Ions and Methylmercury. II. Inorg. Chim. Acta. 1994, 223, 103-107.

11. Julian, R. R.; Hodyss, R.; Beauchamp, J. L. Salt Bridge Stabilization of Charged Zwitterionic Arginine Aggregates in the Gas Phase. J. Am. Chem. Soc. 2001, 123, 3577-3583.

12. Mark, T. D. Mass Spectrometry of Clusters. Adv. Mass Spectrom. 1995, 13, 71-94.

13. Zhou, S. L.; Hamburger, M. Formation of Sodium Cluster Ions in Electrospray Mass Spectrometry. Rapid Commun. Mass Spectrom. 1996, 10, 797-800.

14. Zhang, D.; Wu, L.; Koch, K. J.; Cooks, R. G. Arginine Clusters Generated by Electrospray Ionization and Identified by Tandem Mass Spectrometry. Eur. Mass Spectrom. 1999, 5, 353-361.

15. Zhang, D.; Cooks, R. G. Doubly-Charged Cluster Ions, $\left[(\mathrm{NaCl})_{m}\right.$ $\left.(\mathrm{Na})_{2}\right]^{2+}$ : Magic Numbers, Dissociation, and Structure. Int. J. Mass Spectrom. 2000, 195/196, 667-684.

16. Justes, D. R.; Mitric, R.; Moore, N. A.; Bonacic-Koutecky, V.; Castleman, A. W. Theoretical and Experimental Consideration of the Reactions between VxOy+ and Ethylene. I. Am. Chem. Soc. 2003, 125, 6289-6299.

17. Justes, D. R.; Moore, N. A.; Castleman, A. W. Reactions of Vanadium and Niobium Oxides with Methanol. J. Phys. Chem. B 2004, 108, 3855-3862.

18. Dermota, T. E.; Zhong, Q.; Castleman, A. W. Ultrafast Dynamics in Cluster Systems. Chem. Rev. 2004, 104, 1861-1886.

19. Nemes, P.; Schlosser, G.; Vékey, K. Amino Acid Cluster Formation Studied by Electrospray Ionization Mass Spectrometry. J. Mass Spectrom. 2005, 40, 43-49.

20. Fenn, J. B.; Mann, M.; Meng, C. K.; Wong, S. F.; Whitehouse, C. M. Electrospray Ionization for Mass-Spectrometry of Large Biomolecules. Science 1989, 246, 64-71.

21. Fenn, J. B.; Mann, M.; Meng, C. K.; Wong, S. F.; Whitehouse, C. M. Electrospray Ionization-Principles and Practice. Mass Spectrom. Rev. $1990,9,37-70$.

22. Ramsey, R. S.; Van Berkel, G. J.; McLuckey, S. A.; Glish, G. L. Determination of Pyrimidine Cyclobutane Dimers by Electrospray Ionization/Ion Trap Mass Spectrometry. Biol. Mass Spectrom. 1992, 21, 347-352.

23. Little, D. P.; Chorush, R. A.; Speir, J. P.; Senko, M. W.; Kelleher, N. L.; McLafferty, F. W. Rapid Sequencing of Oligonucleotides by HighResolution Mass Spectrometry. I. Am. Chem. Soc. 1994, 116, 4893-4897.

24. Przybylski, M.; Glocker, M. O. Electrospray Mass Spectrometry of Biomacromolecular Complexes with Noncovalent Interactions-New Analytical Perspectives for Supramolecular Chemistry and Molecular Recognition Processes. Angew. Chem. Int. Ed. 1996, 35, 806-826. 
25. Loo, J. A. Studying Noncovalent Protein Complexes by Electrospray Ionization Mass Spectrometry. Mass Spectrom. Rev. 1997, 16, 1-23.

26. Loo, J. A. Electrospray Ionization Mass Spectrometry: A Technology for Studying Noncovalent Macromolecular Complexes. Int. J. Mass Spectrom. 2000, 200, 175-186.

27. Shelimov, K. B.; Jarrold, M. F. "Denaturation" and Refolding of Cytochrome $c$ in Vacuo. I. Am. Chem. Soc. 1996, 118, 10313-10314.

28. Valentine, S. J.; Anderson, J. G.; Ellington, A. D.; Clemmer, D. E. Disulfide-Intact and -Reduced Lysozyme in the Gas Phase: Conformations and Pathways of Folding and Unfolding, J. Phys. Chem. B 1997, 101, 3891-3900.

29. Hirabayashi, A.; Sakairi, M.; Koizumi, H. Sonic Spray Ionization Method for Atmospheric Pressure Ionization Mass Spectrometry. Anal. Chem. 1994, 66, 4557-4559.

30. Hirabayashi, A.; Sakairi, M.; Koizumi, H. Sonic Spray Mass Spectrometry. Anal. Chem. 1995, 67, 2878-2882.

31. Shiea, J.; Wang, W.-S.; Wang, C.-H.; Chen, P.-S.; Chou, C. -H. Analysis of a Reactive Dimethylenedihydrothiophene in Methylene Chloride by Low-Temperature Atmospheric Pressure Ionization Mass Spectrometry. Anal. Chem. 1996, 68, 1062-1066.

32. Yamaguchi, K. Cold-Spray Ionization Mass Spectrometry: Principle and Applications, J. Mass Spectrom. 2003, 38, 473-490.

33. Takats, Z.; Wiseman, J. M.; Gologan, B.; Cooks, R. G. Electrosonic Spray Ionization. A Gentle Technique for Generating Folded Proteins and Protein Complexes in the Gas Phase and for Studying Ion-Molecule Reactions at Atmospheric Pressure. Anal. Chem. 2004, 76, 4050-4058.

34. Wiseman, J. M.; Takáts, Z.; Gologan, B.; Davisson, V. J.; Cooks, R. G. Direct Characterization of Enzyme-Substrate Complexes by Using Electrosonic Spray Ionization Mass Spectrometry. Angew. Chem. Int. Ed. 2005, 44, 913-916.

35. Takats, Z.; Nanita, S. C.; Cooks, R. G.; Schlosser, G.; Vekey, K. Amino Acid Clusters Formed by Sonic Spray Ionization. Anal. Chem. 2003, 75, 1514-1523.

36. Myung, S.; Julian, R. R.; Nanita, S. C.; Cooks, R. G.; Clemmer, D. E. Formation of Nanometer-Scale Serine Clusters by Sonic Spray. J. Phys. Chem. B 2004, 108, 6105-6111.

37. Zhang, D.; Koch, K. J.; Tao, W. A.; Cooks, R. G. Proceedings of the 48th ASMS Conference on Mass Spectrometry and Allied Topics; Long Beach, CA, June 2000.

38. Cooks, R. G.; Zhang, D.; Koch, K. J.; Gozzo, F. C.; Eberlin, M. N. Chiroselective Self-Directed Octamerization of Serine: Implications for Homochirogenesis. Anal. Chem. 2001, 73, 3646-3655.

39. Hodyss, R.; Julian, R. R.; Beauchamp, J. L. Spontaneous Chiral Separation in Noncovalent Molecular Clusters. Chirality 2001, 13, 703-706.

40. Counterman, A. E.; Clemmer, D. E. Magic Number Clusters of Serine in the Gas Phase. J. Phys. Chem. B 2001, 105, 8092-8096.

41. Julian, R. R.; Hodyss, R.; Kinnear, B.; Jarrold, M.; Beauchamp, J. L. Nanocrystalline Aggregation of Serine Detected by Electrospray Ionization Mass Spectrometry: Origin of the Stable Homochiral Gas Phase Serine Octamer. J. Phys. Chem. B 2002, 106, 1219-1228.

42. Kong, X.; Tsai, I.-A.; Sabu, S.; Han, C.-C.; Lee, Y. T.; Chang, H.-C.; Tu, S.-Y.; Kung, A. H.; Wu, C.-C. Progressive Stabilization of Zwitterionic Structures in $\left[\mathrm{H}(\mathrm{Ser})_{2-8}\right]^{+}$Studied by Infrared Photodissociation Spectroscopy. Angew. Chem. Int. Ed. 2006, 45, 4130-4134.

43. Koch, K. J.; Gozzo, F. C.; Zhang, D.; Eberlin, M. N.; Cooks, R. G. Serine octamer metaclusters: Formation, Structure Elucidation, and Implications for Homochiral Polymerization. Chem. Commun. 2001, 1854-1855.

44. Koch, K. J.; Gozzo, F. C.; Nanita, S. C.; Takats, Z.; Eberlin, M. N.; Cooks, R. G. Chiral Transmission between Amino Acids: Chirally-Selective Amino Acid Substitution in the Serine Octamer as a Possible Step in Homochirogenesis. Angew. Chem. Int. Ed. 2002, 41, 1721-1724.
45. Schalley, C. A.; Weis, P. Unusually Stable Magic Number Clusters of Serine with a Surprising Preference for Homochirality. Int. J. Mass Spectrom. 2002, 221, 9-19.

46. Takats, Z.; Nanita, S. C.; Cooks, R. G. Serine Octamer Reactions Indicators of Prebiotic Relevance. Angew. Chem. Int. Ed. 2003, 42, 3521-3523.

47. Takats, Z.; Nanita, S. C.; Schlosser, G.; Vekey, K.; Cooks, R. G. Atmospheric Pressure Gas-Phase H/D Exchange of Serine Octamers. Anal. Chem. 2003, 75, 6147-6154.

48. Ustyuzhanin, P.; Ustyuzhanin, J.; Lifshitz, C. An Electrospray IonizationFlow Tube Study of H/D Eexchange in Protonated Serine. Int. J. Mass Spectrom. 2003, 223-224, 491-498.

49. Geller, O.; Lifshitz, C. An Electrospray Ionization-Flow Tube Study of H/D Exchange in the Protonated Serine Dimer and Protonated Serine Dipeptide. Int. J. Mass Spectrom. 2003, 227, 77-85.

50. Julian, R. R.; Myung, S.; Clemmer, D. E. Proceedings of the 52nd ASMS Conference on Mass Spectrometry and Allied Topics; Nashville, TN, May 2004

51. Julian, R. R.; Myung, S.; Clemmer, D. E. Spontaneous Anti-Resolution in Heterochiral Clusters of Serine. J. Am. Chem. Soc. 2004, 126, 4110-4111.

52. Takats, Z.; Cooks, R. G. Thermal Formation of Serine Octamer Ions. Chem. Commun. 2004, 444-445.

53. Nanita, S. C.; Takats, Z.; Cooks, R. G. Proceedings of the 52nd ASMS Conference on Mass Spectrometry and Allied Topics; Nashville, TN, May 2004

54. Nanita, S. C.; Takats, Z.; Myung, S.; Clemmer, D. E.; Cooks, R. G. Chiral Enrichment of Serine Via Formation, Dissociation, and Soft-Landing of Octameric Cluster Ions. J. Am. Soc. Mass Spectrom. 2004, 15, 1360-1365.

55. Hwang, H. Y.; Lin, C.; Oh, H.; Breuker, K.; Carpenter, B. K.; McLafferty, F. W. Proceedings of the 52nd ASMS Conference on Mass Spectrometry and Allied Topics; Nashville, TN, May 2004.

56. Hvelplund, P.; Rangama, J.; Liu, B.; Nielsen, A. B.; Nielsen, S. B.; Tomita, S. Proceedings of the 52nd ASMS Conference on Mass Spectrometry and Allied Topics; Nashville, TN, May 2004.

57. O'Hair, R. A. J.; Gronert, S.; Fagin, A. Proceedings of the 52nd ASMS Conference on Mass Spectrometry and Allied Topics; Nashville, TN, May 2004.

58. Mazurek, U.; Reuben, B. G.; McFarland, M. A.; Marshall, A. G.; Lifshitz, C. Proceedings of the 52nd ASMS Conference on Mass Spectrometry and Allied Topics; Nashville, TN, May 2004.

59. Gronert, S.; O'Hair, R. A. J.; Fagin, A. E. Ion/Molecule Reactions of the Protonated Serine Octamer. Chem. Commun. 2004, 1944-1945.

60. Mazurek, U.; McFarland, M. A.; Marshall, A. G.; Lifshitz, C. Isolation of Isomers Based on Hydrogen/Deuterium Exchange in the Gas Phase. Eur. J. Mass Spectrom. 2004, 10, 755-758.

61. Mazurek, U.; Geller, O.; Lifshitz, C.; McFarland, M. A.; Marshall, A. G.; Reuben, B. G. Protonated Serine Octamer Cluster: Structure Elucidation by Gas-Phase H/D Exchange Reactions. J. Phys. Chem. A 2005, 109, 2107-2112.

62. Nanita, S. C.; Cooks, R. G. Negatively-Charged Halide Adducts of Homochiral Serine Octamers. J. Phys. Chem. B 2005, 109, 4748-4753.

63. Nanita, S. C.; Cooks, R. G. Serine Octamers: Cluster Formation, Reactions, and Implications for Biomolecule Homochirality. Angew. Chem. Int. Ed. 2006, 45, 554-569.

64. Wong, S. S.; Röllgen, F. W. The Effect of a Glycerol Matrix on the Cluster Ion Formation from Salts in Secondary Ion Mass Spectrometry. Int. J. Mass Spectrom. Ion Processes 1986, 70, 135-144.

65. Myung, S.; Fioroni, M.; Julian, R. R.; Koeniger, S. L.; Baik, M.-H.; Clemmer, D. E. Chirally Directed Formation of Nanometer-Scale Proline Clusters. J. Am. Chem. Soc. 2006, 128, 10833-10839. 